\title{
A revision of Macromalthinus Pic, 1919 with description of six new species (Coleoptera: Cantharidae: Chauliognathinae)
}

\author{
Gabriel Biffi ${ }^{1}$ \& Robert Constantin ${ }^{2}$ \\ 1 Universidade de São Paulo (USP), Museu de Zoologia (MZUSP). São Paulo, SP, Brasil. \\ ORCID: 0000-0001-7532-3822. E-mail: biffigabriel@gmail.com \\ 2 Saint-Lô, France. E-mail: rconstantin50@gmail.com
}

\begin{abstract}
A revision of the genus Macromalthinus resulted on recognition of twelve species, six of which are herein proposed as new: Macromalthinus belemensis Brancucci, 1981, M. brasiliensis (Pic, 1906), M. globuliventris Brancucci, 1981, M. guyanensis sp. nov., M. luteoapicalis sp. nov., M. maximiceps Pic, 1919, M. orapuensis sp. nov., M. piceiventris sp. nov., M. quadratithorax sp. nov., M. santaremensis Brancucci, 1981, M. schmidli Constantin, 2010 and M. xerophilus sp. nov. No taxonomic changes were necessary in the previously described species, which are distinguished through differential diagnosis and an updated identification key. The type specimens of all species were revisited and their photographs are provided. Discussions on the diagnostic character of each species, general morphology and the first description of wings and female genitalia of Macromalthinus are presented, as well as the first description of the female of M. maximiceps Pic, 1919. Finally, new records and distribution maps are presented for all species.
\end{abstract}

Key-Words. Brazil; French Guiana; Morphology; Neotropical, Taxonomy.

\begin{abstract}
Résumé. La révision du genre Macromalthinus Brancucci, 1981, a permis la reconnaissance de douze espèces, dont six nouvelles: Macromalthinus belemensis Brancucci, 1981, M. brasiliensis (Pic, 1906), M. globuliventris Brancucci, 1981, M. guyanensis sp. nov., M. luteoapicalis sp. nov., M. maximiceps Pic, 1919, M. orapuensis sp. nov., M. piceiventris sp. nov., M. quadratithorax sp. nov., M. santaremensis Brancucci, 1981, M. schmidli Constantin, 2010 et M. xerophilus sp. nov. La femelle de M. maximiceps Pic, 1919, est décrite, sexe nouveau. Le statut des espèces précédemment décrites n'est pas modifié et elles sont caractérisées dans une clé d'identification mise à jour et par des diagnostics différentiels. Les spécimens-types de toutes les espèces ont été examinés et photographiés. Des discussions sont présentées à propos des caractères diagnostiques de chaque espèce, sur la morphologie générale, la première description des ailes et l'appareil génital des femelles de Macromalthinus. Enfin, de nouvelles données et des cartes de distribution sont présentées pour toutes les espèces.
\end{abstract}

Mots-Clés. Brésil; Guyane; Morphologie; Néotropical; Taxonomie.

\section{INTRODUCTION}

Pic (1919) erected Macromalthinus for a single species $M$. maximiceps from French Guiana. The brief original description of the genus did not enable the distinction of Macromalthinus from its closely related genera, like Maronius Gorham, 1881. Brancucci (1981a) revised Macromalthinus and extended the generic diagnosis, proposing as synapomorphies, eyes broadly separated, tarsal claws not toothed, males with fore femur always swollen and abdomen strongly sclerotized and curved under itself. Brancucci (1981a) also transferred Maronius brasiliensis Pic, 1906 to Macromalthinus and described three new species, M. globuliventris,
M. santaremensis and $M$. belemensis. Constantin (2010a) described M. schmidli and later (Constantin, 2010b, 2016) presented new distributional records for M. maximiceps in French Guiana.

The genus currently comprises six species, M. maximiceps (French Guiana), M. globuliventris (Peru), M. santaremensis, M. belemensis and M. brasiliensis (Brazil), and M. schmidli (Ecuador), mostly known only from their type locality or restricted distributions. Upon recent field surveys and access to museum's specimens, six new species of Macromalthinus were discovered and the distribution range of some species was greatly expanded, urging the revaluation of species morphological and distributional boundaries. 


\section{MATERIAL AND METHODS}

Types and additional examined specimens are deposited in the following collections (name of curators specified between parentheses):

BMNH: Natural History Museum, London, United Kingdom (Michael Geiser);

CCo: Collection Robert Constantin, Saint-Lô, France (Robert Constantin);

DZUP: Coleção de Entomologia Pe. Jesus Santiago Moure, Departamento de Zoologia da Universidade Federal do Paraná, Curitiba, Brazil (Lúcia M. Almeida);

FSCA: Florida State Collection of Arthropods, Gainesville, USA (Michael C. Thomas);

INPA: Instituto Nacional de Pesquisas da Amazônia, Manaus, Brazil (Augusto Henriques);

MNHN:Muséum national d'Histoire naturelle, Paris, France (Thierry Deuve);

MNRJ: Museu Nacional do Rio de Janeiro, Rio de Janeiro, Brazil (Marcela L. Monné);

MPEG: Museu Paraense Emílio Goeldi, Belém, Brazil (Orlando T. Silveira);

MZSP: Museu de Zoologia da Universidade de São Paulo, São Paulo, Brazil (Sônia A. Casari);

NHMB: Naturhistorisches Museum Basel, Basel, Switzerland (Matthias Borer);

RPSP: Coleção Entomológica 'Prof. J.M.F. Camargo', Faculdade de Filosofia, Ciências e Letras da Universidade de São Paulo, Ribeirão Preto, Brazil (Eduardo A.B. Almeida);

UFES: Entomological Collection of Universidade Federal do Espírito Santo, Vitória, Brazil (Marcelo T. Tavares);

UFMG: Coleção de Entomologia, Centro de Coleções Taxonômicas da Universidade Federal de Minas Gerais, Belo Horizonte, Brazil (Fernando A. Silveira).

Material collected by the Société entomologique Antilles-Guyane (SEAG, Remire-Montjoly, French Guiana) since 2009, intended for inventory purpose, benefited from good conservation techniques: specimens stayed as short as possible in the liquid trapping medium, provisionally stored in $70 \%$ alcohol, drained on absorbent paper, and preserved by freezing in minute translucent paper bags. The specimens were subsequently prepared and glued on card mounting boards.

Morphological nomenclature and dissection methods follow Brancucci (1980, 1981a).

The terms ventrites (visible abdominal sternites) $\mathrm{VI}$ and VII are used for equivalent abdominal sternites VII and VIII. Examination of the female terminalia and genitalia was done after separation of the last two abdominal segments, followed by a short maceration in $\mathrm{KOH}$ solution and dissection, and finally mounted in a flat drop of mounting medium (DMHF, dimethyl hydantoin formaldehyde on a transparent card (Liberti, 2005).

Illustrations were produced via camera lucida attached to a Carl Zeiss Discovery V8 stereomicroscope.
Photographs were taken with a Canon EOS Rebel T3i camera equipped with a Canon MP-E $65 \mathrm{~mm}$ macro lens, attached to a StackShot macro-rail. Multi-focus images were combined with Zerene Stacker 1.04. Illustrations and photographs were edited in Adobe Photoshop CC.

Distribution maps were made with Quantum GIS version 2.18.7-1 (available at: www.qgis.org), and Carto-Fauna-Flora and Data-Fauna-Flora (Y. Barbier \& P. Rasmond, Mons University, Belgium). Locality records were obtained from specimens labels or the literature (Brancucci, 1981a; Constantin, 2010a, 2016). Data points on the maps correspond to approximate localities, since the available information is often imprecise or inaccurate.

Abbreviations of trapping devices: PV: piège vitre (window trap); FIT: flight interception trap; LT on DZ: conventional light trap with mercury $250 \mathrm{~W}$ lamp on Drop Zone; PVB, PVP: light trap associating a 'Polytrap' FIT and ramp of Blue LED or Pinkish white LED; Slam: freestanding malaise trap.

Abbreviations for measurement indices: TL: total length; $\mathrm{AL}$ : antennal length; OL: ocular length in lateral view; $\mathrm{HW}$ : head width including the eyes; IOW: inter-ocular width; IAW: interval between the antennal sockets; PL: longest pronotum length; PW: widest pronotum width; EL: elytron length from base to apex; EW: elytra combined width at the base. All the measurements are given in millimetres.

\section{RESULTS}

\section{Macromalthinus Pic, 1919} (Figs. 1-65)

Macromalthinus Pic, 1919: 14; Delkeskamp, 1939: 214; Blackwelder, 1945: 369; Miskimen, 1961: 24; Wittmer, 1963: 131; Magis \& Wittmer, 1974: 93; Delkeskamp, 1977: 465; Brancucci, 1980: 298; Brancucci, 1981a: 259; Brancucci, 1981b: 331; Constantin, 2010: 40; Constantin, 2016: 5.

Type species: Macromalthinus maximiceps Pic, 1919 (by monotypy).

Diagnosis: Antennae filiform or slightly flattened, without strong modifications; head large, strongly narrowed posteriorly, vertex concave; eyes strongly developed, prominent; pronotum subquadrate to trapezoidal, constricted laterally near anterior angle; elytra short, exposing wings and abdominal tergites; elytra without sculptural modifications, apex round, slightly swollen; fore femur of males swollen, usually with a ventral tooth near apex; fore tibia slender, without modifications; tarsal claws simple, not toothed; abdomen of males with broad membranes between ventrites, ventrite VII H-shaped, broadly notched anteriorly and posteriorly, ventrite VIII convex, asymmetrical; aedeagus asymmetrical, median lobe elongate, curved; left paramere flat, partially covering dorsal surface of median lobe; right paramere entire, 
not divided or laterally projected; right prolongation of tegmen present, dorsal surface without apophysis; left setiferous prolongation present or absent.

Distribution: Trinidad and Tobago, French Guiana, Brazil, Ecuador and Peru.

\section{List of Macromalthinus species}

\author{
M. belemensis Brancucci, 1981 \\ M. brasiliensis (Pic, 1906) \\ M. globuliventris Brancucci, 1981 \\ M. guyanensis sp. nov. \\ M. luteoapicalis sp. nov. \\ M. maximiceps Pic, 1919 \\ $M$. orapuensis sp. nov. \\ M. piceiventris sp. nov. \\ M. quadratithorax sp. nov. \\ M. santaremensis Brancucci, 1981 \\ M. schmidli Constantin, 2010 \\ M. xerophilus sp. nov.
}

\section{Key to Macromalthinus species}

1 Pronotum subquadrate, slightly constricted laterally near anterior angles (Figs. 11-12)

$1^{\prime}$ Pronotum narrowed anteriorly, strongly constricted laterally near anterior angles (Figs. 7-10).

2 Pronotum bicoloured, with a broad median longitudinal dark brown stripe, margins pale orange. Males: fore femur with a sharp ventral tooth (Fig. 18); ventrite VIII with a short transverse lateral ridge near left margin and a long oblique longitudinal median ridge (Fig. 30); aedeagus without left setiferous prolongation (Fig. 36). Females: ventrite VII short and wide, lateral margins arched, distal margin with three median slightly projected lobes (Fig. 42) ............................... xerophilus sp. nov.

2' Pronotum entirely pale orange, without dark patches. Male and female characters different from above.

3 Thorax and abdomen pale yellow, elytra usually dark brown with a yellow apical spot (Figs. 59, 61). Males: fore femur with a sharp ventral tooth; ventrite VIII with a longitudinal median ridge; aedeagus without left setiferous prolongation (Fig. 65). Females: ventrite VII with a single straight lobe on median apical margin ................ brasiliensis (Pic, 1906)

3' Thorax and abdomen light to dark brown, elytra dark brown at base, light brown at apex. Males: fore femur with a weak rounded ventral tooth (Fig. 17); ventrite VIII without ridges (Fig. 29); aedeagus with a short and broad setiferous prolongation (Fig. 35). Females: ventrite VII with a pair of wide lobes on apical margin (Fig. 41)

M. quadratithorax sp. nov.

4 Pronotum entirely pale orange, without dark patches ............................

4' Pronotum with colouration variable, always with dark patches.............. 7

5 Elytra light brown to black, with a yellow apical patch; abdominal ventrites pale yellow. Males: fore femur with sharp or rounded ventral tooth (Figs. 13, 15)

5' Elytra black, without apical yellow spot; abdominal tergites and ventrites black. Males: fore femur swollen but without ventral tooth (Fig. 16)....... M. piceiventris sp. nov.

6 Males: fore femur with a sharp and strong ventral tooth; ventrite IV flat, without protuberances; aedeagus with a long setiferous prolongation ... ...M. santaremensis Brancucci, 1981
6' Males: fore femur swollen, with a rounded ventral tooth; ventrite IV with a pair of protuberances near lateral margins; aedeagus with a very short setiferous prolongation. M. globuliventris Brancucci, 1981

7 Pronotum wider medially, then abruptly narrowed frontwards (Fig. 53). Males: aedeagus with right paramere very reduced or absent................. 8

7' Pronotum parallel on basal half and slightly narrowed frontwards (Figs. 7-9). Males: aedeagus with right paramere elongate.................... 9

8 Males: fore femur with a strong, acute ventral tooth; ventrite VII broadly notched anteriorly, with straight margins divergent posteriorly; right paramere of aedeagus very reduced. Females: distal margin of ventrite VII broadly emarginated medially, straight laterally...

M. maximiceps Pic, 1919

8' Males: fore femur swollen but without ventral tooth; ventrite VII deeply notched anteriorly and posteriorly margin sinuous, deeply notched; right paramere of aedeagus absent. Females: distal margin of ventrite VII slightly emarginated medially, rounded laterally

M. belemensis Brancucci, 1981

9 Head, pronotum and elytra entirely black...M. schmidli Constantin, 2010

9' Pronotum pale orange with broad dark patches; elytra dark brown to black with yellow apical patches

10 Elytra with broad apical yellow patches; legs mostly light brown, with small darker spot in apex of femora. Males: fore femur with an inconspicuous rounded ventral tooth (Fig. 14).... M. luteoapicalis sp. nov.

$10^{\prime}$ Elytra with reduced apical yellow patches, sometimes limited to a thin line; legs mostly dark brown to black or light brown with broad dark brown spots in the apex of femora. Males: fore femur with a conspicuous sharp to blunt ventral tooth (Figs. 13, 15) 11

11 Pronotum mostly dark brown, lighter near lateral margins; tibiae dark brown to black. Males: aedeagus with right prolongation of tegmen narrowly separated from left setiferous prolongation (Fig. 31). Females: distal margin of ventrite VII straight (Fig. 37).........M. guyanensis sp. nov.

$11^{\prime}$ Pronotum lighter, with broader testaceous lateral areas; tibiae light to dark brown. Males: aedeagus with right prolongation of tegmen broadly separated from left setiferous prolongation (Fig. 33). Females: distal margin of ventrite VII projected at middle forming two small lobes (Fig. 39) ................................................................. orapuensis sp. nov.

\section{New species of Macromalthinus}

\section{Macromalthinus guyanensis sp. nov. (Figs. 1, 7, 13, 19, 25, 31, 37, 43)}

Type material: HOLOTYPE: ${ }^{\text {`: }}$ FRENCH GUIANA: "Guyane française, Massif de Mitaraka, camp DZ, $02^{\circ} 14^{\prime} 4^{\prime \prime} \mathrm{N}$, 54 27'2"W, 25.III.2015, alt. $310 \mathrm{~m}$, Malaise trap Slam, P.H. Dalens, E. Poirier \& A. Mantilleri leg. / expédition La Planète Revisitée, MNHN-PNI Guyane 2015, autorisation APA 973-1" (MNHN) (Fig. 1). PARATYPES (6 $0^{\circ}$, 37 ?). FRENCH GUIANA. Massif de Mitaraka, $02^{\circ} 14^{\prime} 4^{\prime \prime} \mathrm{N}$, $54^{\circ} 27^{\prime} 2^{\prime \prime} \mathrm{W}$, 25.II.2015, light trap on dropping zone, J. Touroult, E. Poirier \& J.H. Yvinec $\left(10^{7} \mathrm{MNHN}\right)$; idem, 01.III.2015, malaise Slam (2 \& MNHN); idem, 02.III.2015, malaise 6 m, (1 9 MNHN, 1 \& CCo); idem, 06.III.2015, malaise Slam (4 \& MNHN, 1 \% CCo); idem, 12.III.2015, malaise Slam, P.H. Dalens, E. Poirier \& A. Mantilleri (1 \% MNHN); idem, 25.III.2015, malaise Slam (1 \& MNHN); idem, Sommet en Cloche, $02^{\circ} 13^{\prime} 41^{\prime \prime} \mathrm{N}, 54^{\circ} 28^{\prime} 05^{\prime \prime} \mathrm{W}$, 24.III.2015, malaise Slam (1 \& MNHN, 1 \& CCo); Maripasoula, Mont Tabulaire Itoupé, 20-30.III.2010, UV light trap on drop 


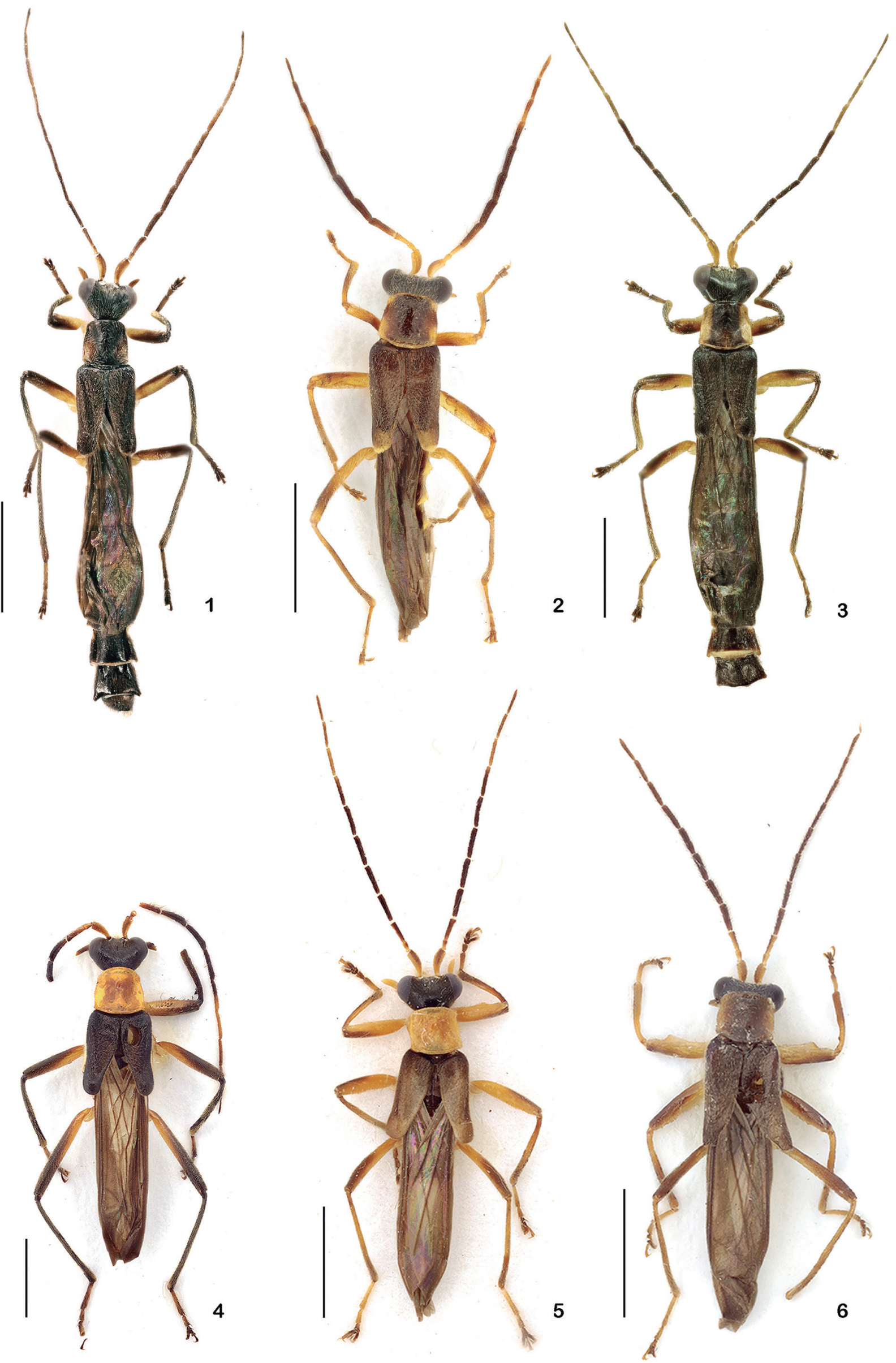

Figures 1-6: Dorsal habitus of Macromalthinus species. (1) M. guyanensis sp. nov. (2) M. Iuteoapicalis sp. nov. (3) M. orapuensis sp. nov. (4) M. piceiventris sp. nov. (5) M. quadratithorax sp. nov. (6) M. xerophilus sp. nov. Scale bars: $2.0 \mathrm{~mm}$. 
zone, alt. $570 \mathrm{~m}$, J. Touroult \& SEAG (1 o' CCo); idem, $03^{\circ} 01^{\prime} 19^{\prime \prime} \mathrm{N}, 53^{\circ} 05^{\prime} 03^{\prime \prime} \mathrm{W}$, alt. $800 \mathrm{~m}, 02 . X I I .2014$, malaise Slam, P.H. Dalens \& SEAG (1 9 MNHN); idem, 07.I.2016, PL (1 9 CCo); idem, 16.I.2016, malaise 6 m (1 o' CCo); SaintElie, Réserve Trinité, savane-roche de la Haute-Kouribso, $04^{\circ} 19^{\prime} \mathrm{N}, 53^{\circ} 17^{\prime} \mathrm{W}$, alt. 210 m, 25.X.2013, P.H. Dalens \& J. Touroult (1 $0^{\prime} \mathrm{CCO}$ ); Mana, Laussat $3 \mathrm{~km} \mathrm{~W}, 05^{\circ} 28^{\prime} \mathrm{N}$, $53^{\circ} 35^{\prime}$ W, 20.V.2010, malaise, G. Lamarre (1 9 CCo); idem, 28.V.2010 (1 \& CCo); idem, 04.VI.2010 (1 \& CCo); idem, 07.X.2010 (1 \& CCo); Risquetout, 8 km W, $04^{\circ} 55.097^{\prime} \mathrm{N}$, $52^{\circ} 33.121^{\prime}$ W, 45 m, MV light, 15.IV.2007, D.G. Hall \& J.E. Eger coll. (1 $\sigma^{\top}$ FSCA); Macouria, forêt littorale de Maya,

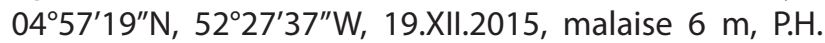
Dalens, F. Robin \& F. Sonzogny (2 \& CCo); Roura, route de Kaw, PK 6, 28.VIII.2010, alt. 180 m, sweeping the understorey, R. Constantin (1 \& CCo); Roura, Montagne des Chevaux, 06.XII.2009, window trap, S. Brûlé, P.H. Dalens \& E. Poirier (1 9 CCo); idem, 13.XII.2009 (1 \% CCo); idem, 09.I.2010 (1 \& CCo); idem, 20.II.2010 (1 \& CCo); idem, 09.II.2010 (2 \& CCo); idem, 17.III.2010 (1 ९ CCo); idem, 10.IV.2010 (1 \& CCo); idem, 19.XII.2010 (1 \& CCo); idem, 26.XII.2010 (1 ㅇ CCo); Régina, Station des Nouragues, Saut Pararé, 03.IX.2009, malaise, S. Brûlé, P.H. Dalens \& E. Poirier (1 o CCo); idem, 23.XI.2009, PV (2 o CCo); idem, 19.II.2010, malaise (1 + CCo).

Differential diagnosis: Head and elytra entirely dark brown; pronotum predominantly dark brown, yellowish near basal angles; males with acute, sharp tooth at distal third of fore femur; ventrite VIII without notches or ridges, with thin apical setae; aedeagus with right prolongation of tegmen truncate, separated from left setiferous prolongation by a narrow notch; left setiferous prolongation short and broad, covered with short thick setae; females: distal margin of ventrite VII straight, not prominent.

Males differ from M. maximiceps and $M$. orapuensis sp. nov. in terms of shape and position of femoral tooth, and by the abdominal ventrite VII medially longer and aedeagus with a less prominent right prolongation of tegmen.

Description: Length: $6.3-8.6 \mathrm{~mm}$. Colouration: Head black; antennae brown, antennomeres I-Il pale yellow ventrally, brown dorsally; maxillary and labial palpi brownish yellow, last palpomere brown; pronotum dark brown, yellowish near posterior angles; elytra and scutellum dark brown; legs dark brown, except coxae and base of femora, yellow; abdomen black (Fig. 1). The colour pattern of the type series from Mitaraka and from Mont Itoupé is slightly variable, mostly with dark brown pronotum, two slight yellowish-brown patches near posterior angles. On the costal series collected at Roura and nearby localities, half of specimens has dark pronotum, while the other half has a pronotal pattern of black median strip surrounded by two narrow to wide yellow sidebands.

Male: Head large, 1.34 times wider than pronotum; temples elongate, strongly narrowed posteriorly; frons deeply depressed between eyes. Eyes strongly de-
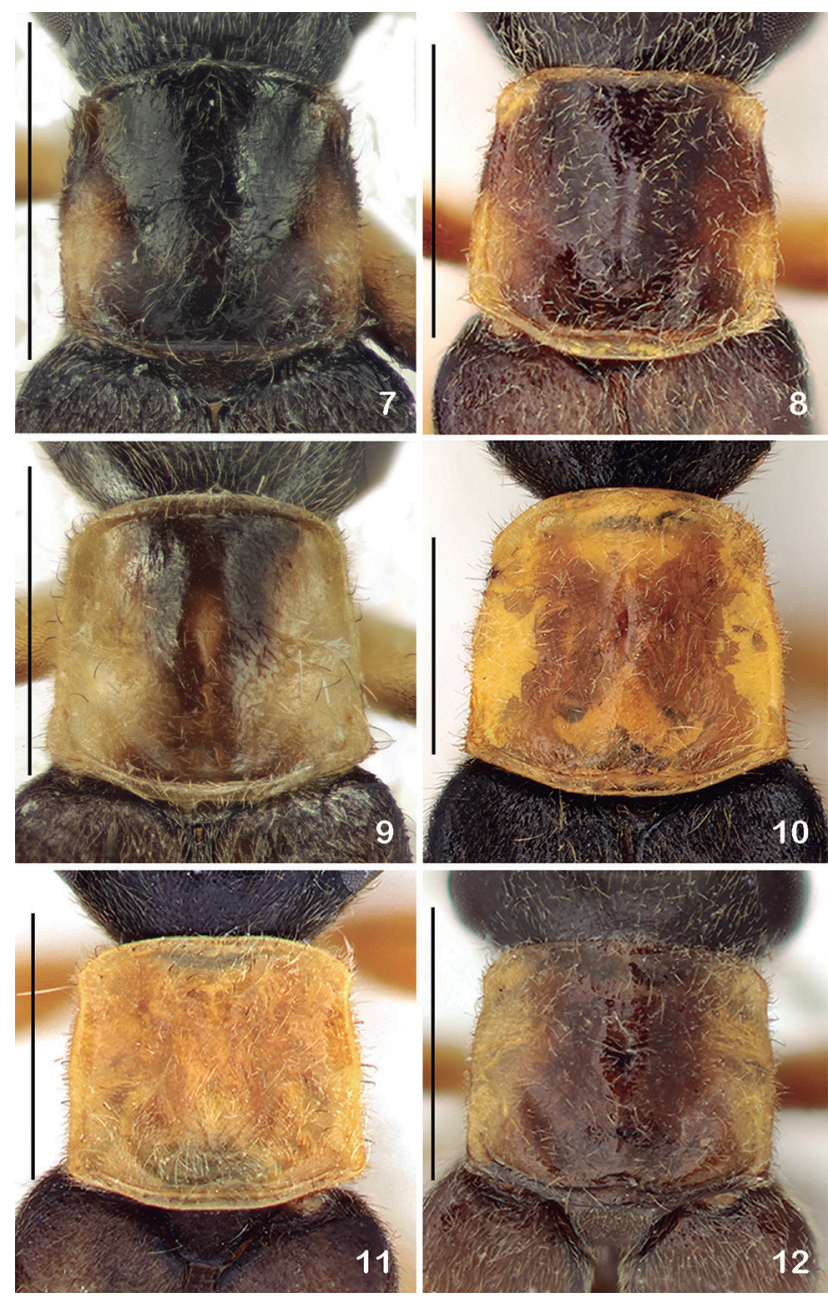

Figures 7-12: Pronotum of Macromalthinus species. (7) M. guyanensis sp. nov. (8) M. luteoapicalis sp. nov. (9) M. orapuensis sp. nov. (10) M. piceiventris sp. nov. (11) M. quadratithorax sp. nov. (12) M. xerophilus sp. nov. Scale bars: $1.0 \mathrm{~mm}$.

veloped, bulging, internal margins converging frontwards. Antennae filiform, slender, antennomeres not compressed dorso-ventrally; antennomere I dilated, 3 times longer than broad. Pronotum (Fig. 7) as long as wide; anterior margin regularly arched; posterior margin arched medially, straight laterally near posterior angles; lateral margins straight, parallel at base, regularly tapering frontwards, constricted near anterior angles; pronotal margins thinly bordered, stronger near anterior and posterior angles; pronotal surface dull, not punctate, with thin, whitish pubescence. Elytra short, thinly punctate, slightly wrinkled, covered with thin whitish setae, obliquely bent backwards; sutures broadly dehiscent from basal third; apex narrower, swollen dorsally, lustrous. Fore femur (Fig. 13) with obtuse ventral tooth near apex; femora, tibiae and tarsomeres increasing in length from fore to hind legs; tarsal claws simple, not toothed. Abdominal tergites and ventrites broadly sclerotized; glandular pores slightly prominent; apical margin of tergite VIII broadly concave; lateral margins extended by a short conical projection; tergite IX longer than wide, asymmetrical, longer on its right side; ventrite VI broadly and deeply notched, membranous posteriorly; ventrite VII (Fig. 19) H-shaped, lateral mar- 
gins slightly arched from apical half, deep and wide membranous area anteriorly, wide and broadly arched notch posteriorly, apical margins rounded laterally; ventrite VIII (Fig. 25) broadly convex, asymmetrical, without notches or ridges, with thin apical setae. Aedeagus (Fig. 31): right prolongation of tegmen truncate, short, weakly oblique, dorsal surface without apophysis, separated from left setiferous prolongation by a narrow notch; apical margin covered with short thick setae; left setiferous prolongation short, broad, covered with short, thick setae; right paramere short, broad, lateral margins parallel; left paramere flat, wider at base, apex rounded, partially covering dorsal surface of median lobe; median lobe wider basally, broadly membranous apically. Measurements of holotype: TL: 8.2; AL: 5.6; HW: 1.18; IOW: 0.42; IAW: 0.15; OL: 0.63; PL: 0.9; PW: 0.88; EL: 1.76; EW: 1.14. Length of each antennomere: al: 0.55; all: 0.19; all:: 0.39; alV: 0.57; aV: 0.6; aVI: 0.62; aVII: 0.6; aVIII: 0.57; aIX: 0.54; aX: 0.5; aXI: 0.5.

Female: Differs from male in having narrower head, eyes smaller, shorter; inter-antennal space wider, frons feebly depressed between eyes; first antennomere slightly swol- len, 3.6 times longer than broad, fore femora simple, not toothed; tergite VIII distinctly emarginated apically; ventrite VI entire, not notched; ventrite VII (Fig. 37) subrectangular, lateral margins arched, distal angles rounded, slightly projected straight distal margin; coxites (Fig. 43): base long, slender, apex very short, broad projection behind styles bearing thin setae; styles fusiform, constricted at base, bearing thick, long setae. Measurements of medium size female paratype: TL: 7.5; AL: 5.4; HW: 1.12; IOW: 0.58; IAW: 0.22; OL: 0.53; PL: 0.92; PW: 0.94; EL: 1.76; EW: 1.36 .

Etymology: The name refers to the locality (French Guiana) where the holotype was collected.

Distribution: French Guiana (Figs. 66, 69).

Natural history: Most of the specimens were collected with interception traps, either during daytime with malaise and windows traps, or at light traps. Only one specimen was collected by sweeping the understorey. This species is widespread in French Guiana and reaches the banks of boundary rivers Maroni and Oyapoc.
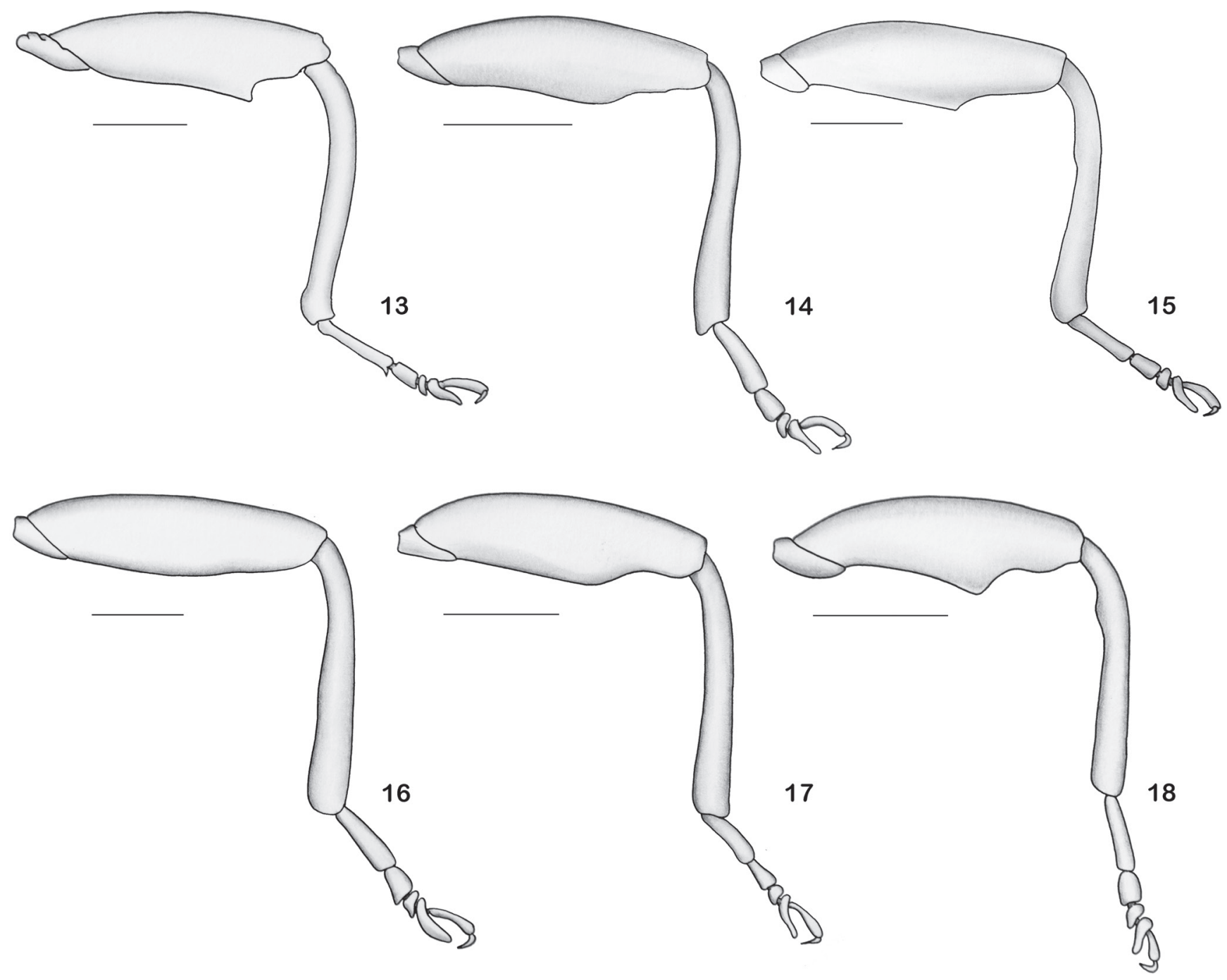

Figures 13-18: Fore femur of Macromalthinus species. (13) M. guyanensis sp. nov. (14) M. luteoapicalis sp. nov. (15) M. orapuensis sp. nov. (16) M. piceiventris sp. nov. (17) M. quadratithorax sp. nov. (18) M. xerophilus sp. nov. Scale bars: $0.5 \mathrm{~mm}$. 


\section{Macromalthinus luteoapicalis sp. nov.}

(Figs. 2, 8, 14, 20, 26, 32, 38, 44)

Type material: HOLOTYPE: $\sigma^{\text {: }}$ BRAZIL. Mato Grosso: Gallery forest, $12^{\circ} 50^{\prime}$ S, $51^{\circ} 47^{\prime}$ W, 05.X.1968, O.W. Richards, R.S.\& R.G.S. Exped. [Royal Society \& Royal Geographical Society], B.M. 1968-240 (BMNH) (Fig. 2). PARATYPES (1 $\sigma^{\prime \prime}$ 2 9). BRAZIL. Mato Grosso: Gallery forest, $12^{\circ} 50^{\prime} \mathrm{S}, 51^{\circ} 47^{\prime} \mathrm{W}$, 30.III.1968, O.W. Richards, R.S.\& R.G.S. Exped., B.M. 1968-240 (1 ơ BMNH); idem, 10.X.1968, O.W. Richards, R.S.\& R.G.S. Exped., B.M. 1968-240 (1 ㅇ BMNH); Chapada dos Guimarães, Parque Nacional da Chapada dos Guimarães, $15^{\circ} 25^{\prime} 46.7^{\prime \prime} \mathrm{S}$, 55 50'41.8"W, 03-13.XI.2008, Almeida, Fernandes, Kawada \& Rosa col (1 9 MZSP).

Differential diagnosis: Pronotum dark brown in the centre, clearing towards borders, margins and angles pale yellow; elytra dark brown, with yellowish to lightbrown apical patch; males: femur swollen, wider medially, with inconspicuous rounded ventral tooth; ventrite VIII with a short, oblique ridge near left margin; aedeagus with right prolongation of tegmen broadly projected dorsally; left setiferous prolongation elongate, wide, with short apical setae; females: abdominal ventrite VII short, wide, lateral margins arched, posterior angles emarginated, posterior margin straight.

Males differ from $M$. belemensis by the presence in the latter of fore femur with an inconspicuous rounded ventral tooth, distal margins of abdominal ventrite VII wider and aedeagus with left paramere present. Distal margin of ventrite VII of females straight (notched in M. belemensis).
Description: Length: $5.6-6.5 \mathrm{~mm}$. Colouration: Head predominantly black, clypeus dark brown; antennae dark brown, testaceous on antennomeres I-III; labium and maxillae light brown, palpomeres light brown to testaceous; mandibles light brown at apex and pale yellow at base; pronotum dark brown at centre, clearing towards borders, margins and angles pale yellow; elytra dark brown with a yellowish to light-brown apical patch; wings dark brown; thorax and abdomen light brown; legs pale yellow to light brown, darker at apex of femora, tibiae and tarsi (Fig. 2).

Males: Head large, transverse, 1.2 times wider than pronotum; temples elongate, strongly tapering posteriorly; vertex and frons concave. Eyes bulging, oblong, prominent. Antennae filiform, flattened dorso-ventrally, densely covered with thin setae; antennomere I wide, II very short, III 0.6 times shorter than I, IV and V nearly as long as $\mathrm{I}$, VI slightly longer than the following ones, progressively decreasing in length apically. Pronotum (Fig. 8) nearly as long as wide; anterior margin slightly arched, lateral margins slightly constricted near anterior angles, sinuate and convergent from anterior half; pronotal surface elevated antero-medially and near posterior angles, forming two lateral shallow grooves, parallel lateral margins, convergent posteriorly. Elytra short, rugulose, densely covered with short and thin setae; sutures dehiscent from posterior half; apex slightly swollen dorsally. Fore femur (Fig. 14) swollen, wider medially, with inconspicuous rounded ventral tooth; femora, tibiae and tarsomeres increasing in length from fore to hind legs; tarsal claws simple, not toothed. Abdominal tergites and sternites sclerotized;
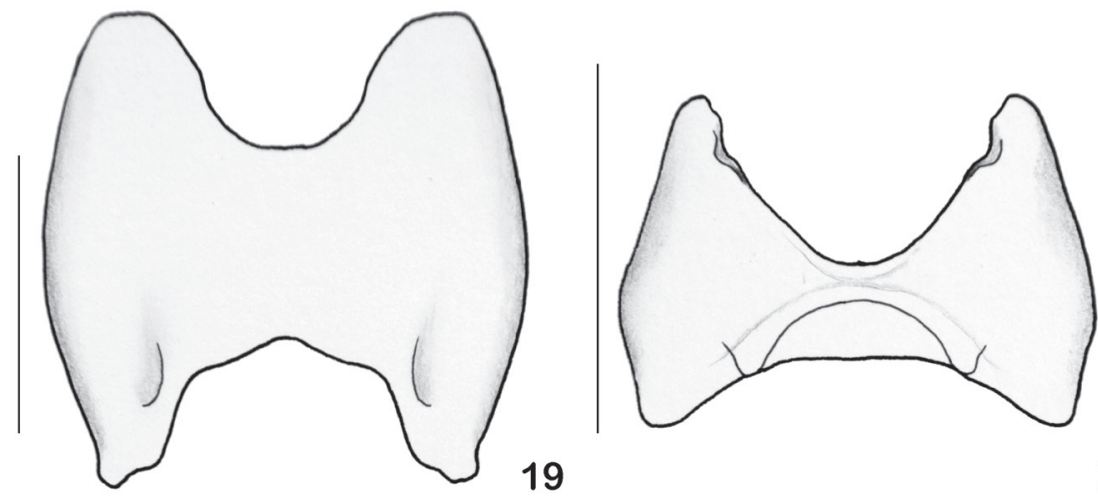

19

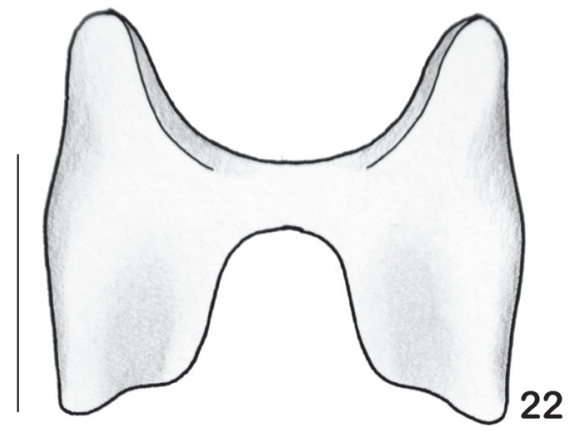

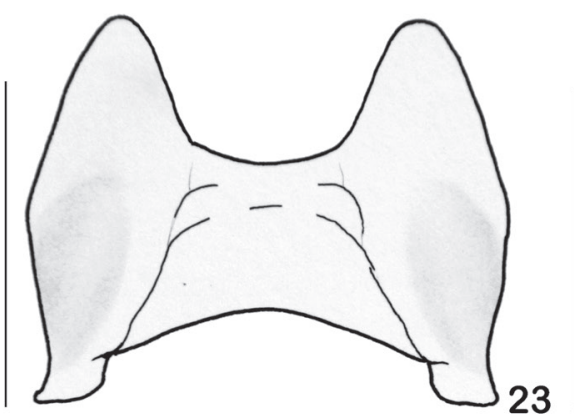

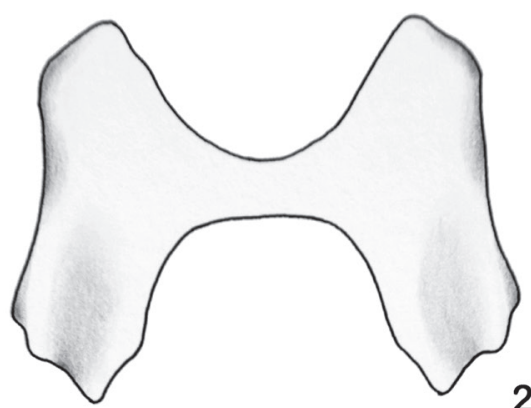

Figures 19-24: Ventrite VII of males of Macromalthinus species. (19) M. guyanensis sp. nov. (20) M. luteoapicalis sp. nov. (21) M. orapuensis sp. nov. (22) M. piceiventris sp. nov. (23) M. quadratithorax sp. nov. (24) M. xerophilus sp. nov. Scale bars: $0.5 \mathrm{~mm}$. 
ventrites densely covered with long thin setae; glandular pores not prominent; distal margin of ventrite VI entire, not notched, slightly membranous; ventrite VII (Fig. 20) $\mathrm{H}$-shaped, lateral margins sinuous, with a broad membranous area anteriorly and a wide posterior notch; ventrite VIII (Fig. 26) asymmetrical, irregularly oblong, strongly convex; a short, oblique ridge near left margin. Aedeagus (Fig. 32) with right prolongation of tegmen broadly projected dorsally, without apophysis on dorsal surface; left setiferous prolongation elongate, wide, with short apical setae; right paramere elongate, straight, apex acute, slightly curved; left paramere elongate, narrow, flat, apex rounded; median lobe straight, broad, apex membranous. Measurements of holotype: TL: 6.0; AL: 4.8; OL: 0.51; HW: 1.12; IOW: 0.57; IAW: 0.20; PL: 0.86; PW: 0.93; EL: 1.8; EW: 1.24. Length of each antennomere: al: 0.3; all: 0.18; alll: 0.30; alV: 0.43; aV: 0.45; aVI: 0.47; aVII: 0.47; aVIII: 0.48; alX: 0.48; aX: 0.43; aXI: 0.46.

Female: Similar to males; eyes smaller, less prominent; fore femora slender, without intumescence or tooth; ventrite VI entire, not notched posteriorly; ventrite VII (Fig. 38) short, wide, lateral margins arched, anterior angles emarginated, posterior margin straight; coxites (Fig. 44) with base elongate, slender, apex very short, with a short, broad projection behind styles bearing few thin setae; styles short, slightly wider apically, bearing some setae of different thicknesses. Measurements of medium size female paratype: $T L$ : $6.5 ; \mathrm{AL}: 4.4 ; \mathrm{OL}: 0.47$; HW: 10.6; IOW: 0.52; IAW: 0.17; PL: 0.82; PW: 0.86; EL: 1.62; EW: 1.14. Length of each antennomere: al: 0.37 ; all: 0.21; alll: 0.26; alV: 0.4; aV: 0.42; aVI: 0.45; aVII: 0.45; aVIII: 0.42; alX: 0.41; aX: 0.39; aXI: 0.44

Etymology: The specific epithet is derivative of the Latin words luteus (yellow) + apicalis (apex), referring to their yellow patches in the apex of elytra.

Distribution: Brazil (Mato Grosso state) (Figs. 66-67).

Locality description: The specimens were collected during an expedition held by the joint Royal Society \& Royal Geographical Society (United Kingdom) sponsorship in cooperation with the National Research Council of Brazil during 1967 and 1969. Brown (1970) describes the vegetation near the base camp, where the specimens were collected, as: "forest (mata), savanna (cerrado) and grassland (campo). The base camp was located near the southern boundary of the Amazonian mata, where, on the interfluves, close-canopied dry forest gives way to woodland cerrado, usually through a short transition of cerradão, a taller denser form of cerrado. In the valleys gallery forest follows the stream sides in both cerrado and dry forest. Campos, varying from shrub-free grassland (campo limpo), to grasslands with occasional trees (campo sujo), characterize valley slopes in the cerrado where soils are saturated in the wet season". Fifty years later, little remains of the original vegetation, since the area is currently threatened by deforestation, extensive farming and livestock.
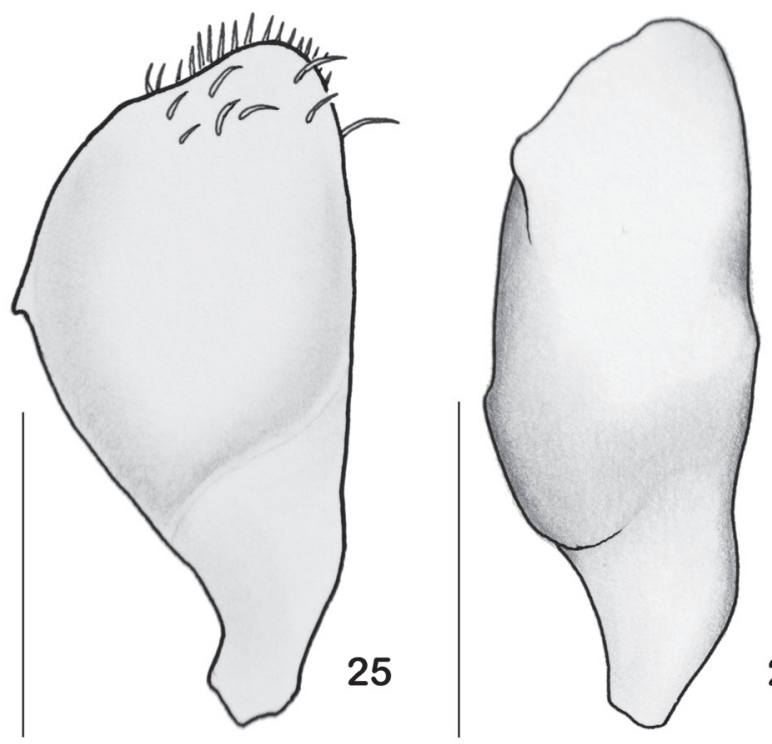

26
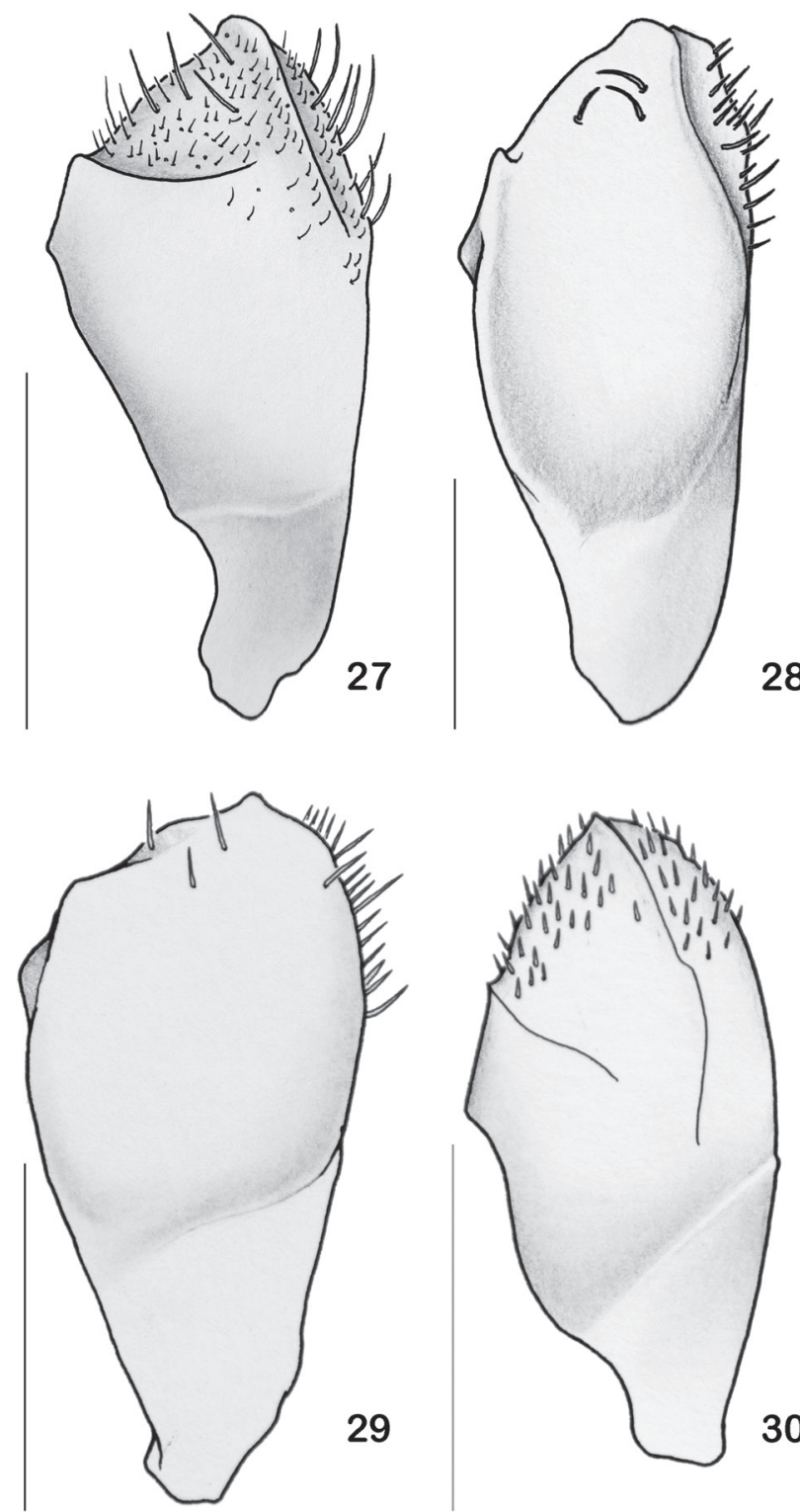

Figures 25-30: Ventrite VIII of males of Macromalthinus species. (25) M. guyanensis sp. nov. (26) M. luteoapicalis sp. nov. (27) M. orapuensis sp. nov. (28) M. piceiventris sp. nov. (29) M. quadratithorax sp. nov. (30) M. xerophilus sp. nov. Scale bars: $0.5 \mathrm{~mm}$. 


\section{Macromalthinus orapuensis sp. nov.}

(Figs. 3, 9, 15, 21, 27, 33, 39, 45)

Type material: HOLOTYPE: $\sigma^{\pi}$ : FRENCH GUIANA. Roura, RN2, PK 65 [national road 2 at km 65], [Rivière] Orapu, Crique Orfion, $04^{\circ} 29^{\prime} 46^{\prime \prime} \mathrm{N}, 52^{\circ} 20^{\prime} 43^{\prime \prime} \mathrm{W}, 01 . X .2016$, Malaise trap, P.H. Dalens \& SEAG (MNHN). (Fig. 3). PARATYPES (1 $0^{\pi}, 6$ \%). FRENCH GUIANA. Roura, RN2, PK 65, Orapu, Crique Orfion, $04^{\circ} 29^{\prime} 46^{\prime \prime} \mathrm{N}, 52^{\circ} 20^{\prime} 43^{\prime \prime} \mathrm{W}$, 01.X.2016, Malaise trap, P.H. Dalens \& SEAG (1 9 MNHN, 1 ơ, 1 o CCo); same locality, 17.IX.2016, Malaise trap, P.H. Dalens \& SEAG (2 9 CCo); Régina, 10 km W, Petite
Montagne Tortue, $04^{\circ} 19^{\prime} \mathrm{N}, 52^{\circ} 14^{\prime} \mathrm{W}, 09 . \mathrm{Vl} .2010$, Malaise trap, G. Lamarre (2 \& CCo).

Differential diagnosis: Pronotum with broad median brown strip from anterior to posterior margins, laterally bordered by one yellow strip each side from anterior to posterior angles; elytra entirely brown; males: fore femur with blunt tooth near apex, notched beyond the apical fourth; aedeagus with right prolongation of tegmen narrowed apically and markedly oblique, separated from left setiferous prolongation by a broad and straight notch; left setiferous prolongation elongate, slender, with few
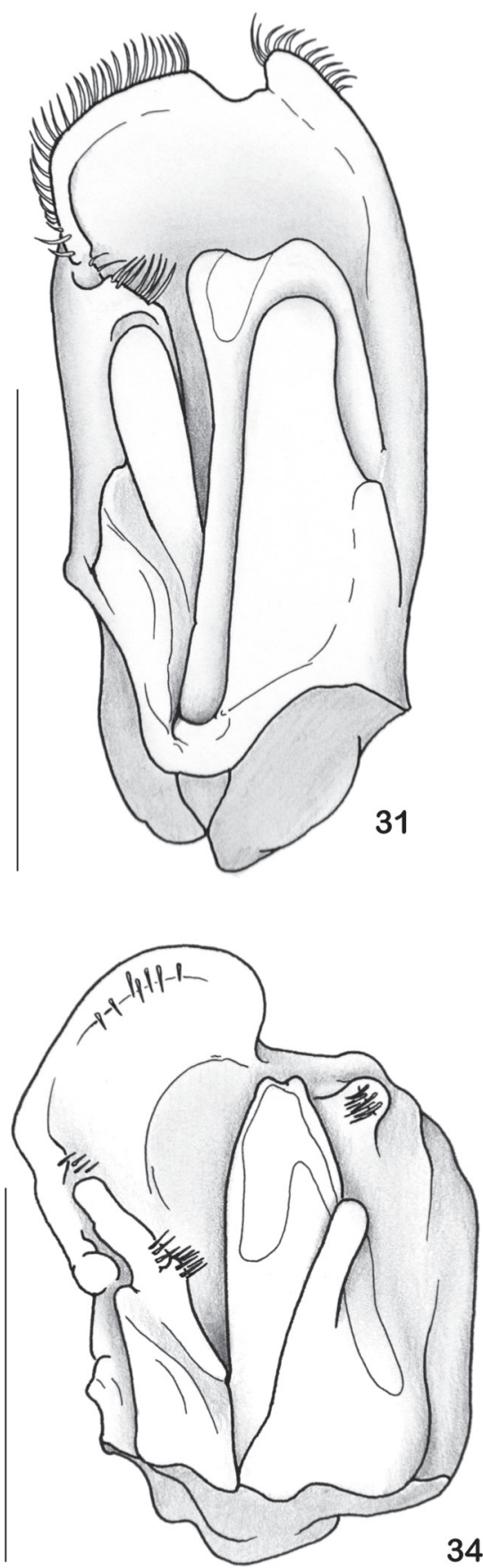
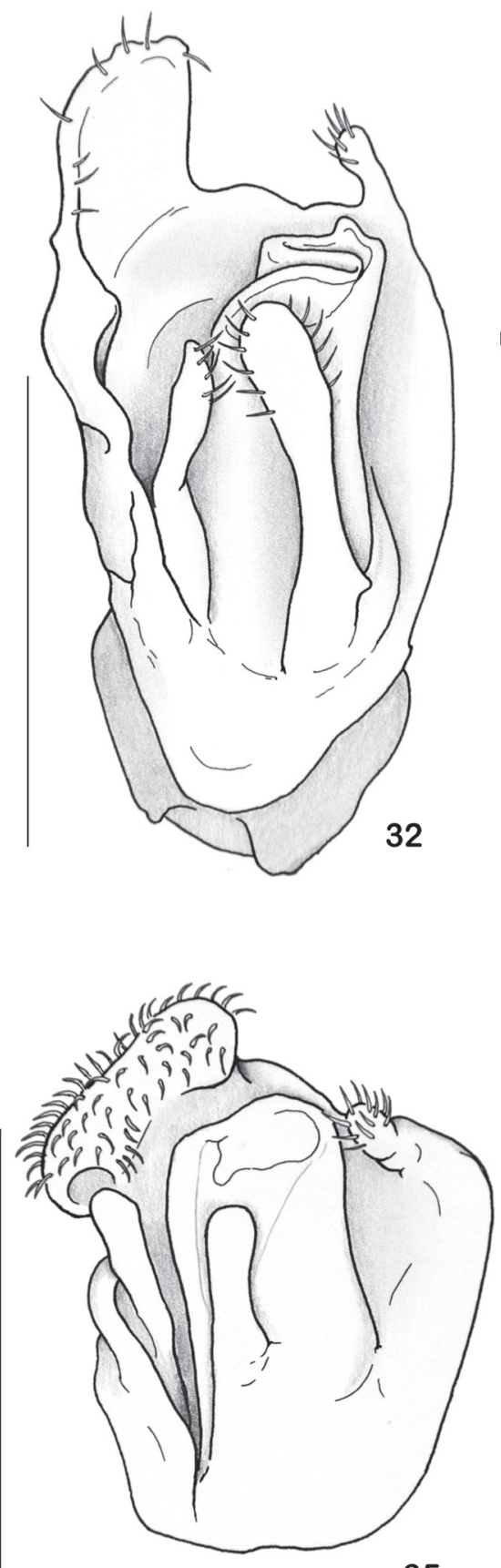

35

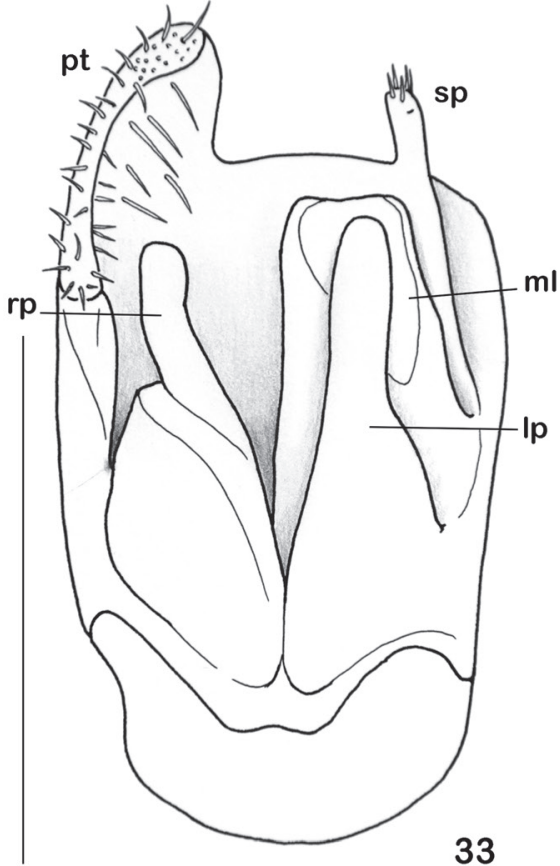

33

Figures 31-36: Aedeagus of Macromalthinus species. (31) M. guyanensis sp. nov. (32) M. luteoapicalis sp. nov. (33) M. orapuensis sp. nov. (34) M. piceiventris sp. nov. (35) M. quadratithorax sp. nov. (36) M. xerophilus sp. nov. Abbreviations: $\mathrm{pt}=$ prolongation of tegmen, $\mathrm{sp}=$ setiferous prolongation, $\mathrm{rp}=$ right paramere, $\mathrm{lp}=$ left paramere, $\mathrm{ml}=$ median lobe. Scale bars: $0.5 \mathrm{~mm}$. 
short apical setae; females: ventrite VII trapezoidal, distal margin projected, notched medially.

Males of M. orapuensis sp. nov. differ from M. maximiceps (Pic) in the narrower and less concave frons between the eyes, antennomeres IV-V not widened and the different aedeagus. Macromalthinus orapuensis sp. nov. is similar to M. guyanensis sp. nov. and differs from the latter in the different apical edge of the aedeagus. Females of $M$. orapuensis sp. nov. differ by the distal margin of ventrite VII projected at middle and with a pair of lobes at apex (slightly projected, nearly straight in M. guyanensis sp. nov. and concave in M. maximiceps).

Description: Length: 7.7-8.9 mm. Colouration: Head black. Maxillary palpi yellow, last palpomere apically infuscate. Antennae brown, antennomeres I-II and base of III testaceous, apico-dorsally infuscate. Pronotum with a broad median brown strip from anterior to posterior margins, laterally bordered by yellow strip each side, from anterior to posterior angles. Scutellum and elytra brown. Legs bicolour, coxae and trochanters yellow, femora yellow dorsally, covered with elongate brown strip on distal half, tibiae and tarsi brownish. Abdomen black (Fig. 3). A male paratype has a lighter colour scheme, pronotum yellow with dark-brown patch anteriorly, legs mostly yellow. One female paratype from Petite Montagne Tortue has a darker colour pattern, with pronotum brown.

Male: Head 1.22 times wider than pronotum; temples elongate, tapering posteriorly; frons depressed between eyes. Eyes developed, convex, internal margins convergent anteriorly. Antennae thin, slender, first antennomere dilated, 3.2 times longer than broad, following not compressed. Pronotum (Fig. 9) 1.12 times wider than long; anterior margin arched, posterior margin rounded medially, sinuate near angles. Lateral margins straight, regularly narrowing anteriorly; margins thinly bordered, stronger near anterior and posterior angles; pronotal surface dull, not punctate, with a thin, whitish pubescence. Elytra short, thinly punctate, slightly wrinkled, covered with thin yellowish setae, obliquely bent backwards; sutures dehiscent from anterior third; apex lustrous, narrower, swollen dorsally. Fore femur (Fig. 15) with a blunt tooth near apex, notched beyond apical fourth. Abdominal tergites and sternites broadly sclerotized; tergite VIII apically emarginated, distal angles prominent, forming a short conical projection; tergite IX as long as wide, asymmetrical, longer on its right side; ventrite VII (Fig. 21) H-shaped, sides arched, with deep, wide membranous area anteriorly, and deep, wider posterior notch; ventrite VIII (Fig. 27) asymmetrical, elongate, strongly convex; short and strong transverse lateral ridge near left margin, long and strong longitudinal ridge along right margin; distal surface densely pubescent. Aedeagus (Fig. 33) with right prolongation of tegmen narrow apically and markedly oblique, separated by a broad and straight notch from left setiferous prolongation; left setiferous prolongation elongate, slender, with few short apical setae; right paramere broad at base, rounded at apex; left paramere flat, wider at base, apex rounded, partially covering dorsal surface of median lobe; median lobe wider basally, broadly membranous apically. Measurements of holotype: TL: 8.9; AL: 5.9; HW: 1.34; IOW: 0.52; IAW: 0.17; OL: 0.68; PL: 0.98; PW: 1.1; EL: 1.84; EW: 1.3.

Female: Length: $7.7-8.3 \mathrm{~mm}$. Similar to light form of Macromalthinus guyanensis but elytra shorter. Ventrite VII (Fig. 39) trapezoidal, longer, distal margin projected medially and notched at apex forming two small lobes; stylus of coxites (Fig. 45) not constricted at base.

Etymology: The name refers to the locality (Orapu river) where the holotype was collected.
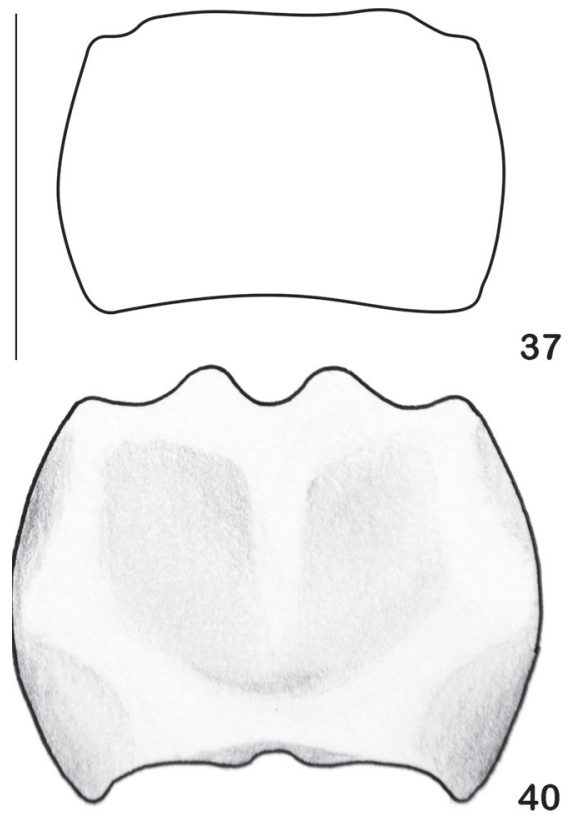
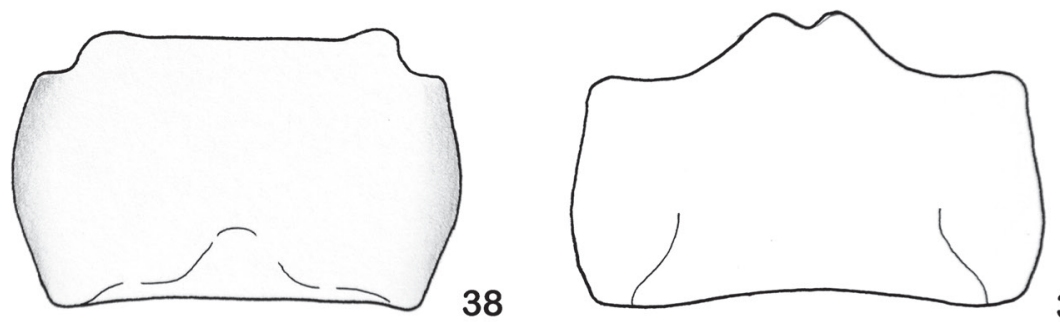

39

Figures 37-42: Ventrite VII of females of Macromalthinus species. (37) M. guyanensis sp. nov. (38) M. Iuteoapicalis sp. nov. (39) M. orapuensis sp. nov. (40) M. piceiventris sp. nov. (41) M. quadratithorax sp. nov. (42) M. xerophilus sp. nov. Scale bars: $0.5 \mathrm{~mm}$. 
Distribution: French Guiana (Figs. 66, 69).

Locality description: The specimens were collected with malaise traps in peculiar natural zones of lowland swamp forests on hydromorphic soils at Crique Orfion and Petite Montagne Tortue. Both localities, southeastwards Cayenne along the National Road of the East to Régina, encompass a large number of protected plants and animals. Crique Orfion enjoys protection under Natural Zone of Ecological, Faunistic and Floristic Interest (ZNIEFF) station's status. "Crique Orfion station with Bactris nancibaensis" (endemic palm tree of the Guyanese littoral) includes over 3.000 hectares of drained forests, lowland swamp forests and swamp forests. Characteristic plants in the permanently flooded zones are Euterpe oleracea (Arecaceae) ('pinot palm','açaí palm'), Symphonia globulifera (Clusiaceae) ('chestick','manil marécage', 'guanandi') and especially Lecythis pneumatophora (Lecythidaceae) ('mahots'). In periodically exposed areas Oenocarpus bataua (Arecareae) ('patawa', 'patauá') is quite abundant in the canopy (Tostain, 2017).

\section{Macromalthinus piceiventris sp. nov. (Figs. 4, 10, 16, 22, 28, 34, 40, 46)}

Type material: HOLOTYPE: $\sigma^{x}$ BRAZIL. Amazonas: Presidente Figueiredo, AM 240, km 24, 02 $35^{\prime} 21^{\prime \prime} S$, $60^{\circ} 06^{\prime} 55^{\prime \prime} \mathrm{W}, 11-12 . \mathrm{XII.2004}$, armadilha de luz mista, F.F. Xavier F. \& G.M. Lourido (INPA) (Fig. 4). PARATYPES (3 $\%$ ). BRAZIL. Amazonas: Manaus, Reserva Ducke, II.1995, armadilha malaise, MGV Barbosa col. (1 \& INPA, 1 \& MZSP 35638); idem, Reserva Ducke, 26 km NE Manaus, X.1995, malaise 1, plot C, Barbosa, M.G.V. (1 ᄋ BMNH 2003-84).

Differential diagnosis: Head black, antennomeres I-II testaceous, slightly darker dorsally, III to half of VII black, half of VII-XI orangish yellow, gradually darker apicad; antennomeres slightly flattened dorso-ventrally; pronotum orangish yellow, sometimes with medial brownish patches; elytra entirely black; abdominal ventrites and tergites dark brown to black; males: fore femur swollen, without distinct tooth; ventrite VIII with a short transverse lateral ridge near left margin and a long longitudinal ridge along right margin; aedeagus with right prolongation of tegmen broadly projected dorsally; left setiferous prolongation short and stout, with a dense tuft of long and thick apical setae; females: ventrite VII short, distal margin with two acute projections in the middle.

Macromalthinus piceiventris sp. nov. differs from M. maximiceps, $M$. belemensis, $M$. santaremensis and $M$. Iuteoapicalis by the dark-brown to black abdomen, fore femur of males without a distinct ventral tooth, aedeagus with a very short setiferous prolongation, and a much longer ventrite VII of females.

Description: Length: $8.4 \mathrm{~mm}$. Colouration: Head and clypeus black; antennomeres I-II testaceous, slightly darker dorsally, III to half of VII black, half of VII-XI orangish yellow, gradually darker apically; labium and maxillae pale yellow, darker on dorsal face of last labial and maxillary palpomeres; pronotum orangish yellow, sometimes with medial brownish patches; elytra black; wings dark brown; thorax and legs dark brown to black, except coxae and base of femora, orange yellow; abdominal ventrites and tergites dark brown to black (Fig. 4).

Males: Head large, 1.1 times wider than pronotum; temples elongate, strongly tapering posteriorly; frons deeply depressed between eyes. Eyes large, bulging, internal margins convergent anteriorly. Antennae filiform, slightly flattened dorso-ventrally, covered with thick setae, longer on ventral sides of antennomeres I-IV; antennomere I elongate, slightly widened apically, II very short, III 2.4 times longer than II; antennomeres III-VII gradually increasing in length, VIII-XI decreasing in length. Pronotum (Fig. 10) as long as wide; anterior margin arched, lateral margins almost straight, gradually narrowed anteriorly, constricted laterally, near anterior angles; pronotal surface elevated antero-medially and near posterior angles, forming two lateral shallow grooves posteriorly convergent and a shallow medial hollow. Elytra short, rugulose, densely covered with short, thin setae; sutures dehiscent from posterior half; lateral margins narrowed after middle; apex swollen dorsally. Fore femur (Fig. 16) swollen,
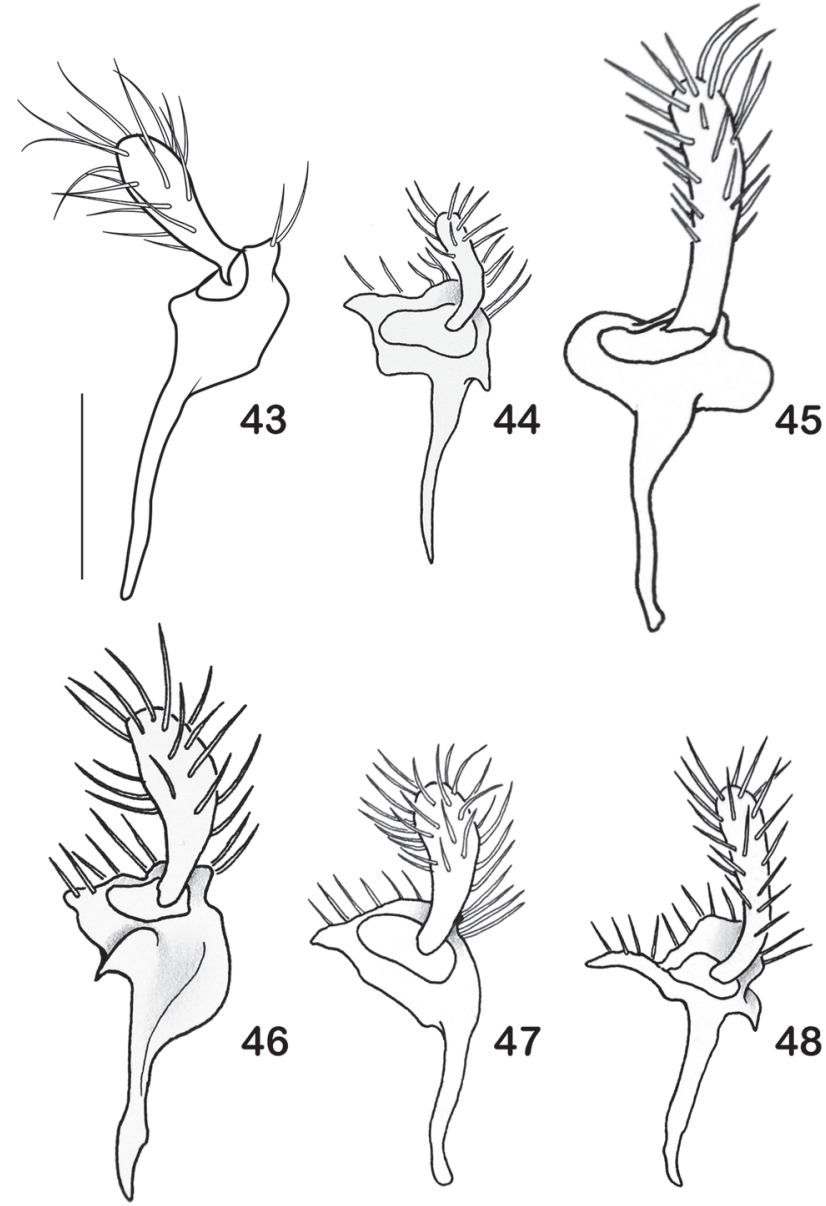

Figures 43-48: Coxites of Macromalthinus species. (43) M. guyanensis sp. nov. (44) M. luteoapicalis sp. nov. (45) M. orapuensis sp. nov. (46) M. piceiventris sp. nov. (47) M. quadratithorax sp. nov. (48) M. xerophilus sp. nov. Scale bars: $0.2 \mathrm{~mm}$. 


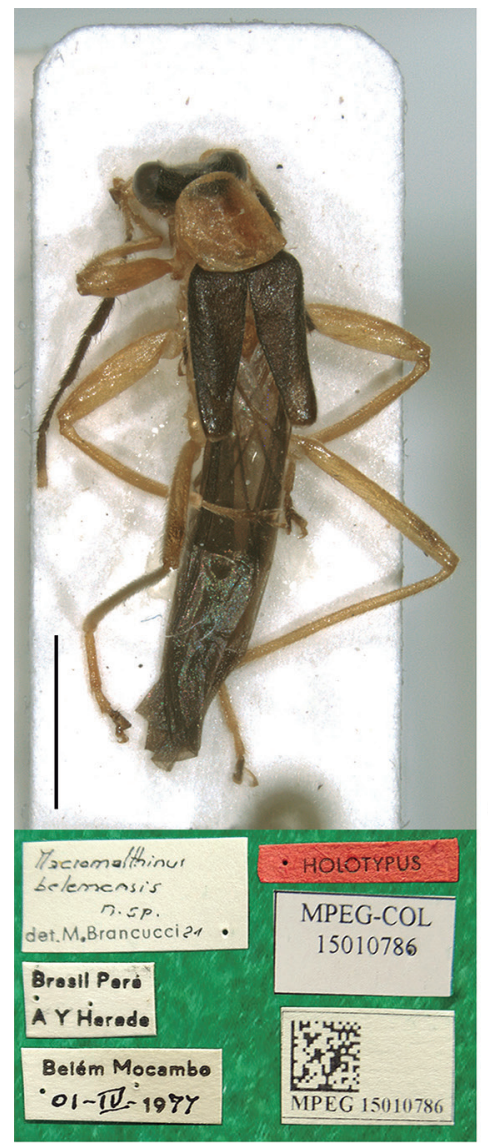

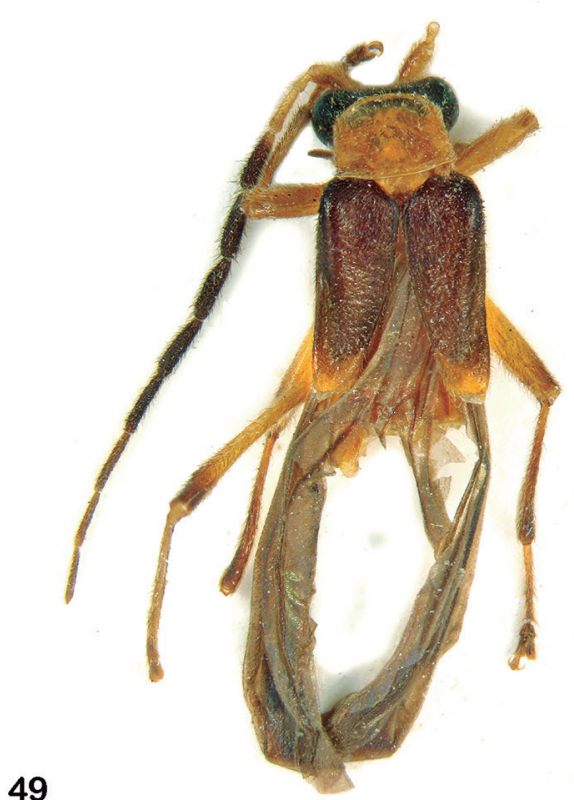

49

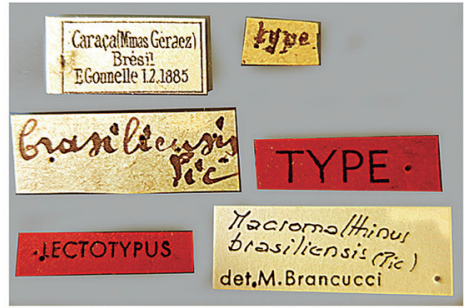

50

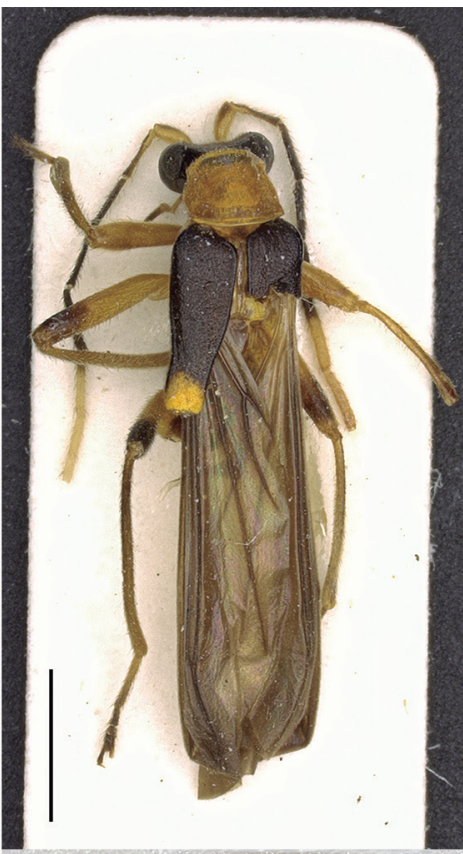

51

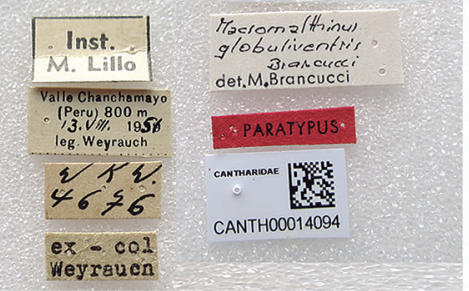

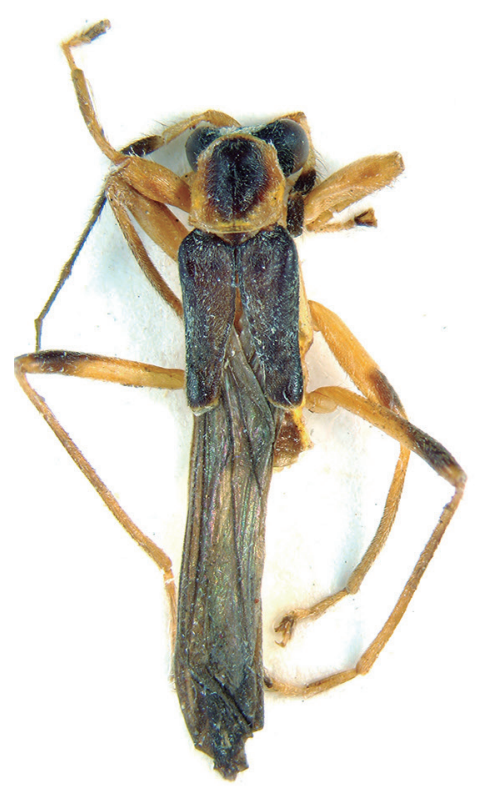

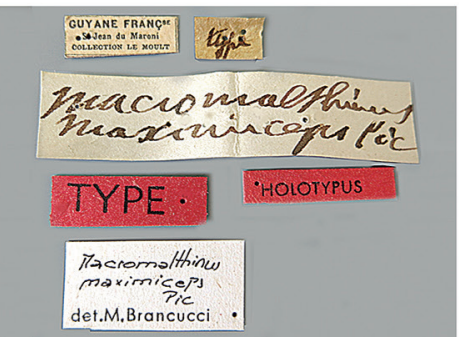

52

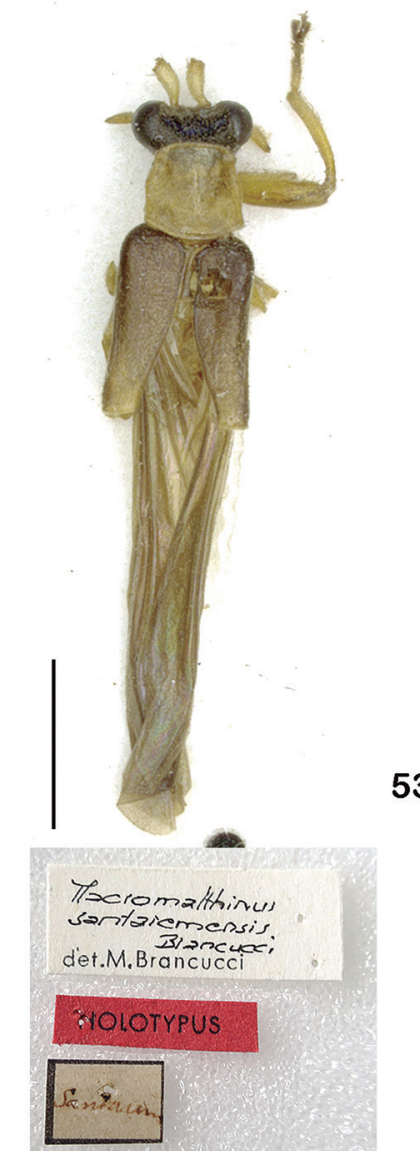

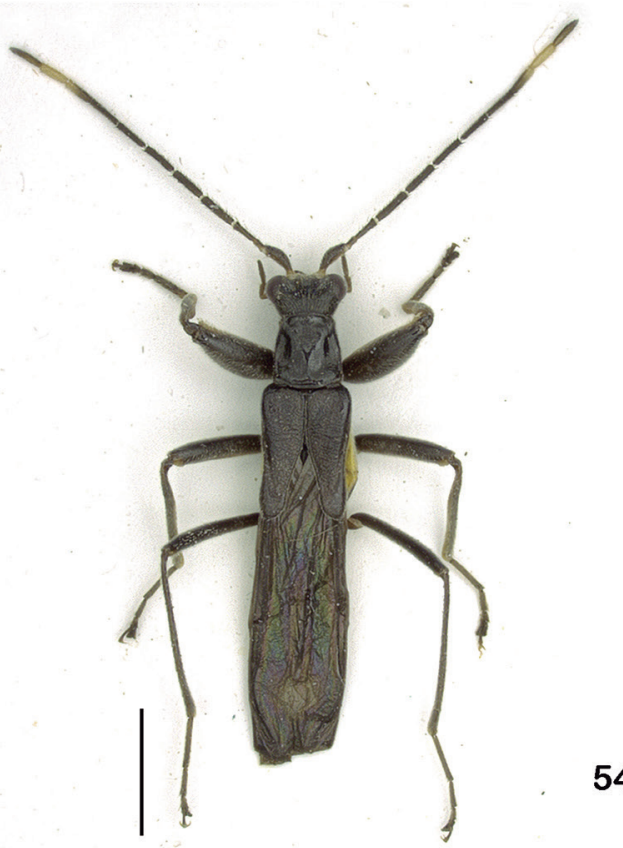

54

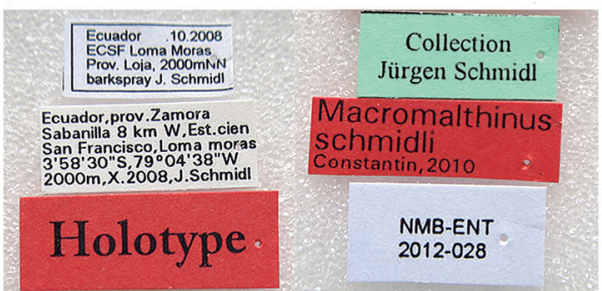

Figures 49-54: Type specimens of Macromalthinus species. (49) M. belemensis Brancucci, 1981 (holotype, MPEG). (50) M. brasiliensis (Pic, 1906) (= Maronius brasiliensis Pic, 1906 (lectotype, MNHN). (51) M. globuliventris Brancucci, 1981 (paratype, NHMB). (52) M. maximiceps Pic, 1919 (lectotype, MNHN). (53) M. santaremensis Brancucci, 1981 (holotype, NHMB). (54) M. schmidli Constantin, 2010 (holotype, NHMB). Scale bars: 2.0 mm. 
without distinct tooth; femora, tibiae and tarsomeres increasing in length from fore to hind legs; tarsal claws simple, not toothed. Abdominal tergites and sternites broadly sclerotized; glandular pores slightly prominent; tergite VIII asymmetrical, notched posteriorly; ventrite VI broadly notched, membranous posteriorly; ventrite VII (Fig. 22) $\mathrm{H}$-shaped, sides sinuate, with deep, wide membranous area anteriorly, and deep, wider posterior notch longer than a half of ventrite; ventrite VIII (Fig. 28) asymmetrical, elongate, strongly convex; short transverse lateral ridge near left margin, long longitudinal ridge along right margin. Aedeagus (Fig. 34) with right prolongation of tegmen broadly projected dorsally, without apophysis on its dorsal surface; left setiferous prolongation short, stout, with dense tuft of long, thick apical setae; right paramere elongate, slightly wider medially; left paramere elongate, flat, apex rounded, partially covering dorsal surface of median lobe; median lobe straight, with long apical membranous surface dorsally. Measurements of holotype: TL: 8.2; AL: 6.7; OL: 0.77; HW: 1.4; IOW: 0.62; IAW: 0.16; PL: 1.21; PW: 0.12; EL: 2.0; EW: 1.6. Length of each antennomere: al: 0.56; all: 0.22; alll: 0.52; alV: 0.63; aV: 0.71; aVI: 0.77; aVII: 0.75; aVIII: 0.72; alX: 0.66; aX: 0.61; aXI: 0.61.

Female: similar to males; differ by eyes smaller and less prominent; inter-antennal space wider, frons feebly depressed between eyes; fore femora slender, without intumescence or tooth; lateral margins of tergite VIII rounded, glandular openings broadly projected posteriorly; ventrite $\mathrm{VI}$ entire, not notched posteriorly; ventrite VII (Fig. 40) elongate, lateral margins arched, posterior margin strongly sinuous, forming two rounded projections in the middle, anterior margin emarginated with weak rounded notch at middle; base of coxites (Fig. 46) elongate, slender, apex wide, rounded laterally, with a projection on distal margin, behind style, bearing few thin setae; styles elongate, strongly wider apically, densely covered with thick setae. Measurements of medium size female paratype: TL: 8.2; AL: 6.8; OL: 0.56; HW: 1.25; IOW: 0.63; IAW: 0.22; PL: 0.97; PW: 1.0; EL: 2.0; EW: 1.3. Length of each antennomere: al: 0.56; all: 0.22 ; all: 0.52 ; alV: 0.63; aV: 0.71; aVI: 0.77; aVII: 0.75; aVIII: 0.72; alX: 0.66; aX: $0.61 ; \mathrm{aXI}: 0.61$.

Etymology: The specific epithet is derivative of the Latin words piceus (black) + ventris (abdomen), referring to the dark-brown to black abdominal sternites of this species.

Distribution: Brazil (Amazonas state) (Fig. 66).

Locality description: One of the localities, Reserva Florestal Ducke, is a well-preserved $100 \mathrm{~km}^{2}$ forest area in central Amazonia, ca. 26 km north-eastern from Manaus. It is currently considered as the most studied site along all the Brazilian Amazon. The main vegetation in the Reserve is terra firme forest, without flooded areas (Ribeiro et al., 1999). The other locality is the municipality of Presidente Figueiredo, whose vegetation is composed of terra firme, dense ombrophilous forest with igapó forests - flooded areas along rivers and lakes formed during rainy seasons.

\section{Macromalthinus quadratithorax sp. nov.} (Figs. 5, 11, 17, 23, 29, 35, 41, 47)

Type material: HOLOTYPE: $\sigma^{\top}$ : TRINIDAD AND TOBAGO. Trinidad, Simla, Arima, Blanchisseuse Rd., VII.1975, Blacklight trap, J. Price (NHMB) (Fig. 5). PARATYPES (4 \%). TRINIDAD AND TOBAGO. Trinidad, W.I., S. Grande, Turure Rd., IV.1969, H \& A Howden Collection (2 \& NHMB); Trinidad, W.I., Morne Bleu, 2700', 15.VIII.1969, H \& A Howden (1 \& NHMB); Trinidad, W.I., Morne Bleu, 2700', 08.VIII.1969, H \& A Howden (1 ᄋ MZSP 35641).

Differential diagnosis: Pronotum subquadrate, entirely pale yellow; elytra greyish brown with yellowish to lightbrown apical patch; males: fore femur slightly swollen, with distinct, rounded ventral tooth; ventrite VIII without ridges; posterior margin notched at left side and acute tip; aedeagus with right prolongation of tegmen short; left setiferous prolongation short and wide, bearing thick, short apical setae; females: ventrite VII short, wide, lateral margins nearly parallel, posterior margin slightly projected.

Macromalthinus quadratithorax sp. nov. differs from the other northern South American species by having
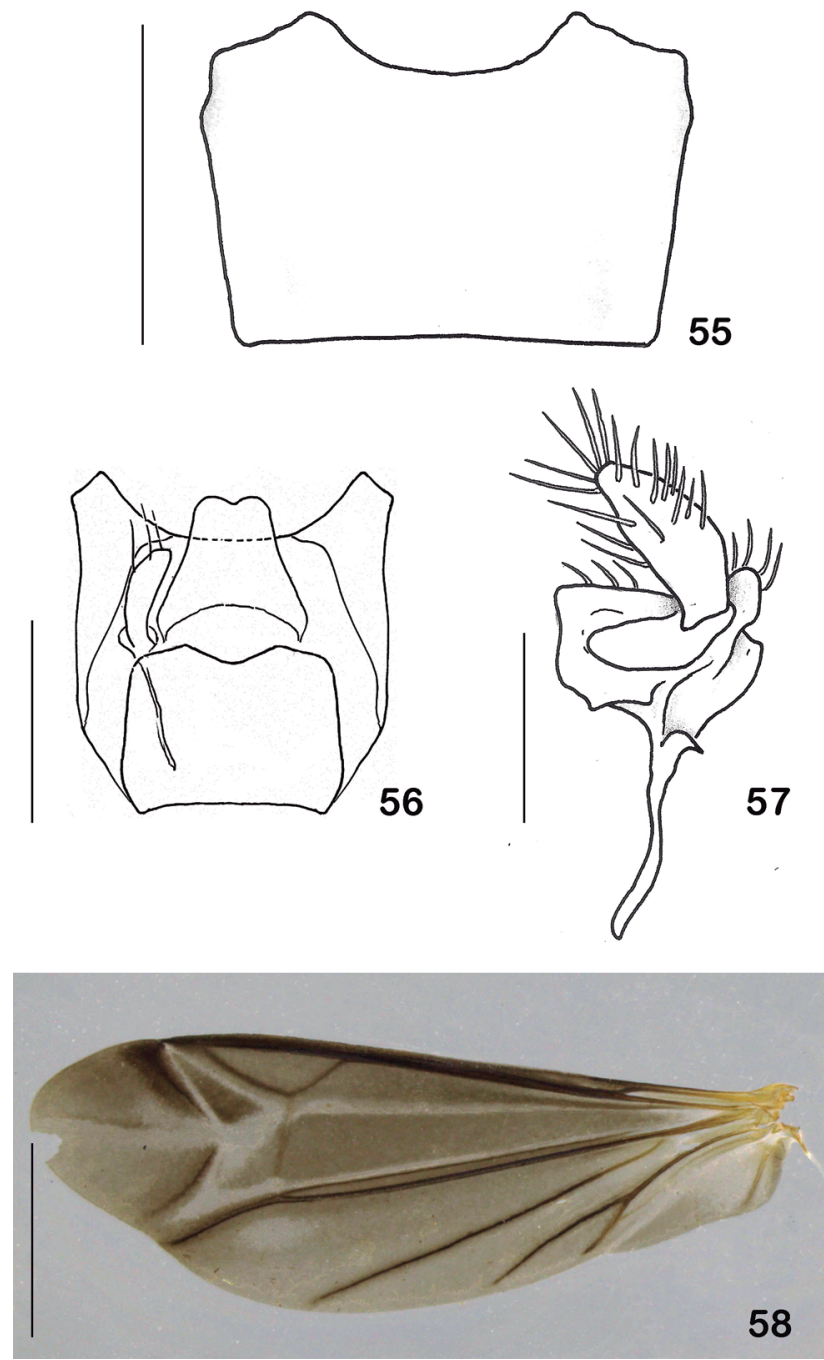

Figures 55-58: Macromalthinus maximiceps, female. (55) Ventrite VII. (56) Apex of abdomen, ventral view. (57) Coxite. (58) Left wing. Scale bars: 55-56: $0.5 \mathrm{~mm} ; 57: 0.2 \mathrm{~mm} ; 58: 2.0 \mathrm{~mm}$. 
the pronotum subquadrate and greyish-brown elytra (the other species have pronotum strongly constricted near anterior angles and dark-brown to black elytra).

Description: Length: 5.7-6.4 mm. Colouration: Head black, frons and clypeus dark brown; antennae dark brown, antennomeres I-III testaceous ventrally, antennomeres IX-XI light brown; labium and maxillae light brown, labial and maxillary palpi testaceous to light brown; pronotum entirely pale yellow; elytra greyish brown, with a yellowish to light-brown apical patch; wings dark brown; legs pale yellow with dark-brown spots on the apex of femora dorsally, dorsal surface of tibiae and distal tarsomeres; thorax and abdominal tergites dark brown, abdominal ventrites light brown (Fig. 5).

Males: Head large, 1.3 times wider than the pronotum, temples elongate, strongly tapering posteriorly, vertex concave. Eyes large, oblong, very prominent. Antennae filiform, slender, covered with thin short setae; antennomere I elongate, II very short, 0.4 the length of I, III twice longer than II, IV-XI nearly same length as I. Pronotum (Fig. 11) subquadrate, 1.1 times wider than long; anterior margin slightly arched, lateral margins almost parallel, slightly constricted near anterior angles; pronotal surface elevated antero-medially and near posterior angles, forming a V-shaped shallow groove posteriorly. Elytra short, rugulose, densely covered with short and thin setae; sutures broadly dehiscent from posterior half; apex swollen dorsally. Legs slender; fore femur (Fig. 17) slightly swollen, with weak, rounded ventral tooth; femora, tibiae and tarsomeres increasing in length from fore to hind legs. Tarsal claws simple, not toothed. Abdominal tergites and sternites sclerotized; ventrites densely covered with long thin setae; glandular pores not prominent; distal margin of ventrite $\mathrm{VI}$ arched and slightly sclerotized; ventrite VII (Fig. 23) H-shaped, lateral margins sinuous, broader anteriorly, with broad membranous area anteriorly and deep posterior notch; ventrite VIII (Fig. 29) asymmetrical, oblong, strongly convex, without ridges; distal margin notched at left side, tip acute. Aedeagus (Fig. 35) with right prolongation of tegmen short, projected dorsally, without apophysis on its dorsal surface; left setiferous prolongation short, wide, bearing thick, short apical setae; right paramere elongate, slightly curved, with slight constriction near apex; left paramere elongate, narrow, flat, apex rounded; median lobe straight, broad, apex membranous. Measurements of holotype: TL: 6.0; AL: 4.8; OL: 0.51; HW: 1.12; IOW: 0.57; IAW: 0.2; PL: 0.86; PW: 0.93; EL: 1.8; EW: 1.24. Length of each antennomere: al: 0.37; all: 0.18; alll: 0.30; alV: 0.43; aV: 0.45; aVI: 0.47; aVII: 0.47; aVIII: 0.48; alX: 0.48; aX: 0.43; aXI: 0.46.

Female: similar to male; eyes smaller, less prominent; fore femora slender, without intumescence or tooth; ventrite VI entire, not notched posteriorly; ventrite VII (Fig. 41) short, wide, lateral margins arched, slightly narrowed near angles, posterior margin slightly projected, strongly sinuous, forming two rounded lobes; base of coxites (Fig. 47) elongate, slender, apex very short, with short and broad projection behind styles bearing few thin setae; styles short, slightly wider apically, bearing thick setae. Measurements of medium size female paratype: TL: 5.6; AL: 5.12; OL: 0.55; HW: 1.15; IOW: 0.58; IAW: 0.21; PL: 0.87; PW: 0.97; EL: 1.70; EW: 1.22. Length of each antennomere: al: 0.46; all: 0.12; alll: 0.38; alV: 0.51; aV: 0.53; aVI: 0.53; aVII: 0.53; aVIII: 0.55; alX: 0.52; aX: 0.47; aXI: 0.47 .

Etymology: The specific epithet is derivative of the Latin words quadratus (square) + thorax (pronotum), referring to the shape of the pronotum in this species.

Distribution: Trinidad and Tobago (Fig. 66).

\section{Macromalthinus xerophilus sp. nov. (Figs. 6, 12, 18, 24, 30, 36, 42, 48)}

Type material: HOLOTYPE: ơ: BRAZIL. Pernambuco: Caruaru, 900 m, V.1972, Joaquim Lima leg. (DZUP 273509) (DZUP) (Fig. 6). PARATYPES (2 $0^{\circ}, 6$ 9): BRAZIL. Pernambuco: Caruaru, V.1972, Joaquim Lima leg. (1 ơ MZSP 35640, 1 ㅇ MZSP 35639, 1 ơ DZUP 376064, 5 DZUP 273503, 273505, 273506, 273508, 273510).

Differential diagnosis: Pronotum subquadrate, pale brown at lateral margins, with wide median dark-brown patch; elytra entirely dark brown; males: fore femur slightly swollen, with distinct, sharp, ventral tooth; ventrite VIII with short transverse lateral ridge near left margin, and elongate, oblique longitudinal median ridge; aedeagus with right prolongation of tegmen truncate, short and narrow; left setiferous prolongation absent; females: ventrite VII short, wide, lateral margins arched, posterior margin projected, with three small lobes at apex. Macromalthinus xerophilus sp. nov. resembles M. brasiliensis (Pic, 1906) but differs by the smaller size, darker colour and particular characters of aedeagus, ventrites VII and VIII of males and ventrite VII of females.

Besides the size and colour, M. xerophilus sp. nov. differs from M. brasiliensis by the fore femur of males with a stronger and sharper ventral tooth, and posterior margin of ventrite VII of females more prominent, forming small rounded lobes.

Description: Length: $5.3-6.0 \mathrm{~mm}$. Colouration: Head black, clypeus and mandibles dark brown; antennae dark brown, lighter on antennomeres I-III and IX-XI; labial and maxillary palpi light brown; pronotum pale brown laterally, with wide median dark brown patch; elytra, wings, thorax and abdomen dark brown; legs pale brown, darker on dorsal surface of femora and apex of tibiae and tarsi; ventrites I-VI light brown, tergites and ventrite VII dark brown (Fig. 6).

Males: Head large, 1.2 times wider than the pronotum, temples elongate, strongly tapering posteriorly, vertex concave. Eyes large, oblong, very prominent. Antennae filiform, slightly flattened dorso-ventrally, covered with 
thick short setae; antennomere I elongate, wider apically, II very short, 0.5 the length of I, III slightly longer than II, IV-XI nearly the same length as I. Pronotum (Fig. 12) 1.1 times wider than long; anterior margin slightly arched, lateral margins nearly parallel, slightly constricted near anterior angles; pronotal surface elevated antero-medially and near posterior angles, forming two lateral shallow grooves convergent posteriorly. Elytra short, rugulose, densely covered with short and thin setae; sutures broadly dehiscent from posterior half; apex swollen dorsally. Legs slender; fore femur (Fig. 18) slightly swollen, with a distinct, sharp, ventral tooth; femora, tibiae and tarsomeres increasing in length from fore to hind legs. Tarsal claws simple, not toothed. Abdominal tergites and sternites sclerotized, densely covered with long and thick setae; glandular pores not prominent; posterior margin of ventrites I-V overlapping the base of subsequent ones; ventrite VI broadly notched, membranous posteriorly; ventrite VII (Fig. 24) H-shaped, lateral margins roundly emarginated, with deep and wide membranous area anteriorly, wide and broadly arched posterior notch; ventrite VIII (Fig. 30) asymmetrical, oblong, strongly convex; short transverse lateral ridge near left margin, long oblique longitudinal median ridge. Aedeagus (Fig. 36) with right prolongation of tegmen truncate, short, narrow, without apophysis on dorsal surface; left setiferous prolongation absent; right paramere elongate, flat, apex acute; left paramere elongate, flat, apex rounded, partially covering dorsal surface of median lobe; median lobe straight with long apical membranous surface dorsally. Measurements of holotype: TL: 5.2; AL: 4.1; OL: 0.56; HW: 1.0; IOW: 0.46; IAW: 0.12; PL: 0.77; PW: 1.0; EL: 1.6; EW: 1.1. Length of each antennomere: al: 0.37 ; all: 0.18 ; alll: 0.26; alV: 0.40; aV: 0.38; aVI: 0.41; aVII: 0.41; aVIII: 0.40; aIX: 0.38; aX: 0.36; aXI: 0.37.

Female: similar to males; eyes smaller, less prominent; fore femora slender, without intumescence or tooth; abdomen less sclerotized; ventrite VI entire, not notched posteriorly; ventrite VII (Fig. 42) short, wide, lateral margins arched, posterior margin prominent, with three small lobes at middle; coxites (Fig. 48) with base elongate, slender, apex very short, with a broad projection behind styles bearing few thin setae; styles elongate, slightly wider apically, bearing thick and long setae. Measurements of medium size female paratype: TL: 6.0; AL: 4.8; OL: 0.51; HW: 1.12; IOW: 0.57; IAW: 0.2; PL: 0.86; PW: 0.93; EL: 1.8; EW: 1.24. Length of each antennomere: al: 0.37; all: 0.18; alll: 0.30; alV: 0.43; aV: 0.45; aVI: 0.47; aVII: 0.47; aVIII: 0.48; alX: 0.48; aX: 0.43; aXI: 0.46.

Etymology: The specific epithet is allusive to the dry climate of the type locality (Caruaru).

Distribution: Brazil (Pernambuco state) (Fig. 66).

Locality description: $M$. xerophilus sp. nov. is recorded in the Agreste region, a transition zone between the Atlantic forest and the semiarid Caatinga biome in Northeastern Brazil. The vegetation in the Agreste at Caruaru is char- acterized as arboreal deciduous thorny vegetation (Alcoforado-Filho et al., 2003).

\section{Remarks and new records for Macromalthinus species}

\section{Macromalthinus belemensis Brancucci, 1981 (Fig. 49)}

Macromalthinus belemensis Brancucci, 1981a: 262.

Material examined: HOLOTYPE ơ: [BRAZIL] Pará, Belém (Mocambo), 01.IV.1977, AY Harada (MPEG 15010786) (MPEG) (Fig. 49).

PARATYPES. BRAZIL. Pará: Belém (Mocambo), 05.III.1977, MF Torres (1 ơ NHMB); idem, 01.IV.1977, AY Harada (1 \& NHMB); Utinga, 25.IV.1961, J. \& B. Bechyné (1 \& MPEG); Santarém, '53./60' ['Brazil, Santarém, Bates, purchased from Stevens'; information from BMNH accessions registry] (1 $\left.\sigma^{7} \mathrm{BMNH}\right)$;'Para' (1 o' MNHN); [Amazonas] 'Ega' [Tefé] (1 ơ MNHN). Amapá: Serra Lombard (Limão), 23.III.1961, J. \& B. Bechyné (1 \& MPEG).

Other specimens: BRAZIL. Pará: Belém (Mocambo), 17.I.1980, M.F. Torres (1 † MPEG); Melgaço, Caxiuanã ECFPn, 01.V.1999, Percurso 2, malaise, O. Silveira \& J. Dias

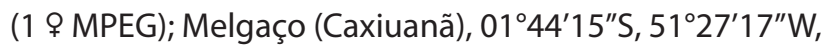
22.III.2006, malaise 8, J.O. Dias col. (1 ؟ MZSP). Amapá: Serra Lombard (Limão), 03.IX.1961, J. \& B. Bechyné (1 \& MPEG). Mato Grosso: (gallery forest), $12^{\circ} 50^{\prime} \mathrm{S}$, 51 ${ }^{\circ} 45^{\prime}$ W, 10-28.III.1968, B.E. Freeman, Roy. Soc. - Roy. Geog. Soc. Xavantina-Cachimbo Exped. 1967-1969 (1 $0^{7}$ 1 o BMNH 1973-292); idem, $12^{\circ} 50^{\prime} \mathrm{S}, 51^{\circ} 47^{\prime} \mathrm{W}, 26 . X .1968$, O.W. Richards (1 ơ BMNH 1968-260); idem, 05.X.1968, O.W. Richards (1 ơ BMNH 1968-260); idem, 13.III.1968, O.W. Richards (on Cecropia) (1 9 BMNH 1968-260); idem, 25.III.1968, O.W. Richards (1 \& BMNH 1968-260); idem, (Campo) 27.IX.1968, O.W. Richards (1 9 BMNH 1968-260).

Differential diagnosis: Head black; antennae brown, except antennomeres I-III and VIII-IX, pale yellow; pronotum testaceous with a wide median brown patch; elytra entirely dark brown; males: fore femur swollen, compressed ventrally, without distinct tooth; aedeagus with right prolongation of tegmen broadly projected dorsally; left setiferous prolongation long and slender; right paramere absent; left paramere wider apically; females: ventrite VII short and wide, lateral margins arched, distal margin concave.

Males of $M$. belemensis differ from the other Amazonian species by the fore femur swollen but without a distinct ventral tooth.

Distribution: Brazil (Amapá, Pará, Amazonas and Mato Grosso states). Macromalthinus belemensis is recorded for the first time in Mato Grosso state (Fig. 66).

Locality description: According to their labels data, the specimens from Mato Grosso state were collected by the Royal Society \& Royal Geographical Society expedition from 1967-1979 in forest galleries and grasslands. 


\section{Macromalthinus brasiliensis (Pic, 1906) (Figs. 50, 59-65)}

Maronius brasiliensis Pic, 1906: 22; Delkeskamp, 1939: 214; Blackwelder, 1945: 369; Delkeskamp, 1977: 465.

Macromalthinus brasiliensis; Brancucci, 1981a: 268; Biffi \& Casari, 2017: 131.

Material examined: LECTOTYPE ơ: BRAZIL. Minas Gerais: Caraça, XII.1885, E. Gounelle (MNHN) (Fig. 50).

PARALECTOTYPE: BRAZIL. Minas Gerais: Caraça, XII.1885, E. Gounelle (1 ơ MNHN).

Other specimens: BRAZIL. Minas Gerais: Serra do Caraça, 27.XI-05.XII.1972, Exp. Mus. Zool. leg. (3 @ MZSP 30642-30644); Nova Lima (mata), 1958'07.4"S, 4351'22.7"W, 07-22.XI.2015, malaise, A.R. Lima leg. (1 ㅇ UFMG ICO 1800203); idem, 08.XI.2015-29.XI.2015 (1 \& UFMG ICO 1800202); Poços de Caldas (Morro São Domingos), 12.II.1969, J. Becker, O. Roppa \& O. Leoncini leg. (2 \& MNRJ); Itajubá (Reserva Biológica Municipal da Serra dos Toledos), 25.VIII.2016, S.P. Rosa \& A.C. Lopes col. (1 ㅇ MZSP 10344); idem, IX-X.2015, malaise, Rosa col. (1 ơ MZSP); idem, 24.IX-15.X.2015, Rosa \& Dias col. (3 ơ, 4 \& MZSP); idem, 15.X-08.XI.2015, Rosa col. (15 o", 8 \% MZSP); idem, 08.XI-06.XII.2015, malaises 1 and 3, Dias \& Rosa col. (6 ox, 19 \% MZSP); XI.2015-I.2016, malaise, Rosa \& Dias col. (2 ơ MZSP); idem, 06.XII.2015-04. II.2016, malaise, Rosa col. (3 ᄋ MZSP); idem, 02.XI-05. XII.2017, Rosa col. (17 ơ, 14 ㅇ MZSP); idem, 08.XI-06. XII.2017, malaise, Rosa \& Dias col. (2 o", 2 \% MZSP). Espírito Santo: Atílio Vivácqua (Serra das Torres), 2059'52.6"S, 4112'49.8"W, 14-19.IV.2007, Malaise, Ponto 5, C. Waichert \& equipe col. (N.01017) (1 \& UFES); Santa Teresa (Estação Biológica de Santa Lúcia), Malaise P2 Trilha, 11-14.XII.2012, M.T. Tavares \& eq. col. (N.1718) (1 $\%$ UFES); idem, Malaise P2 Bosque, 11-14.XII.2012 M.T. Tavares \& eq. col. (N.1719) (1 ơ UFES); Santa Teresa (Reserva Biológica de Augusto Ruschi), Trilha

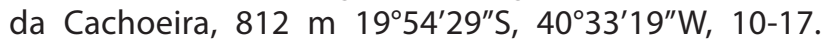
XII.2012, arm. Malaise 6, C.O. Azevedo e eq. col. (N.1745) (4 9 UFES); idem, arm. Malaise 12, C.O. Azevedo e eq. col. (N.1751) (1 \& UFES); Ibitirama (Parque Nacional do Caparaó, Santa Marta), alt. 1.050 m, 20²9'42"S, 41 ${ }^{\circ} 43^{\prime} 56^{\prime \prime} \mathrm{W}$, arm. 01, 06-13.III.2013, arm. Malaise, C.O. Azevedo \& F.B. Fraga col. (N.01769) (2 o UFES); idem, arm. 04, 06-13.III.2013, arm. Malaise, C.O. Azevedo \& F.B. Fraga col. (N.01772) (2 \& UFES); idem, trilha da Toca de São Jorge, alt. 1230 m, 20²7'57"S, 4144'42"W, arm. 31, 16-23.III.2013, arm. Malaise, C.O. Azevedo \& F.B. Fraga col. (N.01799) (1 o UFES); idem, arm. 39, 16-23.III.2013, arm. Malaise, C.O. Azevedo \& F.B. Fraga col. (N.01807) (1 $q$ UFES); Divino de São Lourenço (Parque Nacional do Caparaó), trilha do Facão de Pedra, alt. 1,500 m, $20^{\circ} 24^{\prime} 30^{\prime \prime}$ S, 4147'06"W, arm. 22, 15-22.III.2013, arm. Malaise, C.O. Azevedo \& F.B. Fraga col. (N.01790) (1 9 UFES); idem, arm. 23, 15-22.III.2013, arm. Malaise, C.O. Azevedo \& F.B. Fraga col. (N.01791) (1 9 UFES); Rio de Janeiro: Friburgo, II.1933, C.F.M.L. leg. (1 \& MNRJ); Petrópolis, 05-07.III.1962, J. Bechyné leg. (1 \& MZSP); Teresópolis, 02-05.XII.1958, Martinez, Werner, Alvarenga e Seabra leg. (1 ㅇ DZUP 273511); Teresópolis, Pq. N. Serra dos Órgãos, casa do pesquisador, 16.xii.2016, Simeão Moraes leg. (1 \& MZSP); São Paulo: São Paulo (Jardim Botânico), 2338'20"S, 46³7'10"W, 25.I.2013, Biffi, G. col. (1 \& MZSP 30648); idem, 07.XII.2013, Biffi, G. col. (2 o', 1 \& MZSP 30654-30656); Jundiaí (Reserva Biológica Serra do Japi), I-III.2008, malaise, L.C. Lecci leg. (1 o7 MZSP 30640); idem, (Reserva Biológica Serra do Japi, trilha da cachoeira do Paraíso, riacho Paraíso), $23^{\circ} 14^{\prime} \mathrm{S}, 46^{\circ} 57^{\prime} \mathrm{W}$, 1,050 m, 25.II-12.III.2008, malaise, Lecci LC \& Nascimento EA leg. (1 o' MZSP 30641); idem, 2314'20"S, 46 57'27"W, 23-25.I.2012, Nascimento E.A., Biffi G \& Fernandes F.R. col. (1 9 MZSP 30652); Salesópolis (Estação Biológica de Boracéia), 2338'29"S, 4551'22"W, 24.XII.2008-07.I.2009, malaise, Nihei col. (4 o' MZSP 30647, 30649-30651); idem, $23^{\circ} 39^{\prime} 26.0^{\prime \prime} \mathrm{S}, 45^{\circ} 53^{\prime} 32.1^{\prime \prime} \mathrm{W}, 06-09 . X I I .2012$, Ferreira, V.S. col. (1 ơ MZSP 30645); idem, 11-13.II.2012, Expedição MZUSP col. (1 \& MZSP 30661); idem, 2339'15"S, 455'22"W, 16-21.XI.2017, arm. luz, Expedição MZUSP col. (1 \& MZSP); idem, 08.I.2008, malaise 1, A.S. Soares col. (2 o' MZSP 30660, 30663); idem, Trilha do Poço Verde

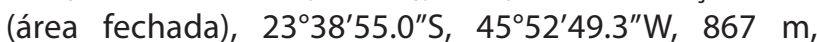
09-15.l.2003, malaise 1, ACC Macedo \& JS Freitas col. (1 \& MZSP 30653); Campos do Jordão, 15.IX.2017, Rosa col. (1 MZSP); idem, 10.XII.2017, Rosa col. (1 \& MZSP); Bertioga (Parque Estadual Restinga de Beritoga, fazenda Içassu), 234'06"S, 4603'09"W, 16.II.2013, Biffi, G. \& Ament, D.C. col. (1 o' MZSP 30662); idem, 05.I-16.II.2013, malaise, Biffi, Cezar \& Fuhrmann col. (1 $\sigma^{x}$, 2 \& MZSP 30657-30659) idem, 23.XI.2012-05.I.2013 (1 o', 2 q RPSP). Paraná: Antonina (Reserva Sapitanduba), 22.XII.1986, malaise (Lev. Ent. PROFAUPAR) (1 \& DZUP 273501); idem, 24.XI.1986 (1 ९ DZUP 273502); Jundiaí do Sul (Fazenda Monte Verde), 14.XII.1987, malaise (Lev. Ent. PROFAUPAR) (3 ox, 1 ㅇ DZUP 273533, 273545, 273546, 273550); idem, 16.XI.1987 (4 ơ DZUP 273539-273542); idem, 02.XI.1987 (1 ơ DZUP 273543); idem, 21.XII.1987 (3 q DZUP 273547-273549); idem, 23.XI.1987 (7 ơ, 3 q DZUP 273527-273532, 273535-273538); idem, 04.I.1988 (1 o', 1 9 DZUP 273554-273555); idem, 07.XII.1987 (1 ه' DZUP 273544); idem, 09.XI.1987 (1 ơ DZUP 273534); Ponta Grossa (Passo do Pupo), -25.101 -49.937, 14-15. XI.2015, Biffi, G. Nascimento, E.A., Prado, L.R. \& Ray, A. col. (3 o MZSP 30665-30667); idem, PN Campos Gerais, $25^{\circ} 06^{\prime} 02.85^{\prime \prime}$, 49 $56^{\prime} 20.32^{\prime \prime}$ W 18.XII.2014, Nascimento, E.A. \& Bressan, T.D. col. (1 9 MZSP 30664); idem, Reserva IAPAR, BR 376, 07.XII.1987, malaise (Lev. Ent. PROFAUPAR) (2 o', 1 \% DZUP 273551-273553). Santa Catarina: Nova Teutonia, II.1936, B. Pohl (1 \& MZSP 30646).

Differential diagnosis: Pronotum subquadrate, entirely orangish yellow, without dark patches; elytra brown with apical yellow patches; males: fore femur swollen, with distinct ventral tooth; ventrite VIII smooth, without ridges; aedeagus with right prolongation of tegmen truncate, short, narrow; left setiferous prolongation absent; females: ventrite VII short, wide, distal margin projected posteriorly.

This species differs from $M$. xerophilus sp. nov. by having larger size, pronotum, thorax and abdomen spotless, 
pale to orangish yellow, fore femur of males with a truncate ventral tooth.

Distribution: Brazil (Minas Gerais, Espírito Santo, Rio de Janeiro, São Paulo, Paraná and Santa Catarina states) (Fig. 66-67).

Localities description: This species is widely found along the southeastern and southern Atlantic forest, from the seashore to highlands over to $1,600 \mathrm{~m}$, and from humid costal to dryer inland areas.

Natural history: Macromalthinus brasiliensis is a rather common species in southeastern Brazil, frequently collected with malaise traps. Despite the abundance of specimens, little is known about their natural history. Mendes et al. (2015) studied the range of altitudinal distribution of Macromalthinus brasiliensis in the Atlantic forest in Parque Nacional da Serra dos Orgãos, Rio de Janeiro state. The authors collected 799 specimens distributed between $350 \mathrm{~m}$ and 1,250 $\mathrm{m}$ altitude, with a peak of abundance at $700 \mathrm{~m}$ altitude and equivalent ration between males and females. Larvae of this species were found in a gully and fed on termites (Biffi \& Casari, 2017). In the laboratory, females of $M$. brasiliensis were observed laying large masses of eggs under the substrate.

\section{Macromalthinus globuliventris Brancucci, 1981} (Fig. 51)

Macromalthinus globuliventris Brancucci, 1981a: 266; Constantin \& Chaboo, 2016: 200.

Material examined: PARATYPE: PERU. Valle Chanchamayo, 800 m, 13.VIII.1951, Weyrauch leg. (1 or NHMB) (Fig. 51).

Other specimens: "17128, Amazon, Degand, Fry coll, 1905-100" (1 ơ BMNH); "34465, Amazon, Fry coll, 1905-100" (1 ơ BMNH).

Differential diagnosis: Head black; antenna brown, except antennomeres I-III and VII-VIII (sometimes IX), testaceous; pronotum pale yellow, elytra black with apical yellow patches; males: fore femur swollen, with rounded ventral tooth; ventrite IV with a pair of protuberances near posterior margin; ventrite VIII compressed apically, with longitudinal ridge and an arched, left transversal ridge; aedeagus with right prolongation of tegmen broadly projected dorsally; left setiferous prolongation vestigial, with a tuft of setae; females: abdominal ventrite VII long, posterior margin slightly projected.

It differs from all the other species by having a pair of protuberances on ventrite IV of males.

Distribution: Peru. The non-type studied specimens are labelled only as 'Amazon', and no other explicit locality information is available (Fig. 66).

\section{Macromalthinus maximiceps Pic, 1919 (Fig. 52, 55-58)}

Macromalthinus maximiceps Pic, 1919: 15; Delkeskamp, 1939: 215; Blackwelder, 1945: 369; Delkeskamp, 1977: 467; Brancucci, 1981a: 260; Constantin, 2010a: 41; Constantin, 2010b: 25; Constantin, 2016: 27.

Material examined: LECTOTYPE o': [FRENCH GUIANA] St. Jean du Maroni, collection Le Moult (MNHN) (Fig. 52). Other specimens: FRENCH GUIANA. Cayenne, AlicotoOyapock, 13.xi.1969, 'piège lumineux' (Guyane Mission Balachowsky-Gruner) (1 $\left.\sigma^{7} \mathrm{NHMB}\right) ; 30$ km S Cayenne, Crossroad N1/D5, XII.2002-2003, Michael Balke (1 ९ BMNH 2004-46); Roura, Kaw Rd., 27 km SE, MV light, 21.IV.2007, J.E. Eger coll. (1 9 FSCA); idem, 6 km W Montagne des

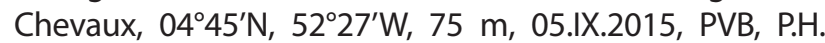
Dalens, F. Robin, F. Sonzogny leg. (1 ơ, 1 @ MZSP, 1 \& CCo); idem, 11.VII.2009, PV (1 o' CCo); idem, 20.VIII.2009, PL (1 \& CCo); idem, 06.XII.2009, PV (2 \& CCo); idem, 03.V.2010, PV (2 9 CCo); idem, 01.II.2011, PV (1 o' CCo); idem, 10.VI.2012, PV (1 \& CCo); idem, 08.VII.2012, Slam, (1 o" CCo); idem, 20.VII.2013, PVB (2 + CCo); idem, 21.IX.2013, Slam (1 q CCo); idem, 28.IX.2013, PVB (1 o CCo); idem, 18.I.2014, PVB (1 o' CCo); idem, 12.IX.2015, PVP (1 o' CCo); idem, 12.IX.2015, PVB (1 9 CCo); idem, 05.XII.2015, PVB (1 \& CCo); Régina, Station des Nouragues, Camp Inselberg, 27.X.2010, PV (1 9 CCo); idem, 13.X.2012. PL (1 $\sigma^{\top}$ CCo); Saint-Elie, Réserve Trinité, Crique Aya, $04^{\circ} 35^{\prime} \mathrm{N}, 53^{\circ} 28^{\prime} \mathrm{W}, 10 . \mathrm{XI} .2013$, light trap with GemLight, P.H. Dalens \& J. Touroult (1 \& CCo); Maripasoula, Mont Tabulaire Itoupé, 27.XI.2014, PL (1 9 CCo); Maripasoula, Massif de Mitaraka, 06.III.2015, Slam (1 9 MNHN); idem, 25.III.2015, alt. 310 m, PL (1 \& MNHN).

Differential diagnosis: Head black; antennae brown, except antennomeres I-III and VIII-IX, testaceous; pronotum testaceous with a wide median brown patch; elytra entirely dark brown; males: fore femur swollen, with an acute, sharp median ventral tooth; aedeagus with right prolongation of tegmen broadly projected dorsally; left setiferous prolongation elongate, slender; right paramere absent; females: ventrite VII short, wide, posterior margin widely emarginated medially.

Macromalthinus maximiceps differs from M. guyanensis sp. nov., M. orapuensis sp. nov. and $M$. santaremensis by the absence of right paramere. It differs from $M$. belemensis by the strong and sharp ventral tooth on fore femur of males. Females of $M$. maximiceps differ from the other species by the widely emarginated distal margin of ventrite VII.

Additional description: Brancucci (1981a) provided a redescription of $M$. maximiceps based only on two male specimens. The study of a larger series of specimens enables the observation of colour variations and the first description of females, given below.

Male: Length: 9.5-10.5 mm. Colouration: Colour pattern of body rather constant, except the extension of the brown median patch on the pronotum. Shape of aedeagus constant. 
Females (Figs. 55-58): (new description). Length: 8.1-10.3 mm. Head black. Pronotum with large brown patch surrounded by yellow borders, wider laterally and posteriorly. Elytra reddish brown, with thin apical yellow line, sometimes missing. Legs yellow, apical black marks on femora; meso- and metatarsi brown. Abdominal tergites reddish brown; ventrites yellow, except last one, black. Head 1.25 times wider than pronotum. Frons feebly depressed between eyes. Eyes large but not bulging. Pronotum as long as wide, wider medially, lateral edges slightly constricted behind anterior angles. Elytra 1.4 times longer than wide together at base, contiguous on anterior third; narrowing, concave, divergent posteriorly; apex narrow, swollen, lustrous; elytral surface thinly punctate, covered with short, thin yellowish setae, obliquely bent backwards. Ventrite VII (Fig. 55) short, wider apically, lateral margins straight, posterior margin widely emarginated medially. Tergite VIII (Fig. 56) wider apically, posterior margin roundly emarginated; tergite IX (Fig. 56) small, subtriangular, elongate, apex tapering, incised medially; Stylus of coxites (Fig. 57) slightly constricted at base and apex. Measurements of medium size female: TL: 9.6; AL: 6.9; HW: 1.4; IOW: 0.82; IAW: 0.24; OL: 0.64; PL: 1.12; PW: 1.12; EL: 2.14; EW: 1.54.

Remarks: Females differ from males by having narrower head, smaller eyes and frons less depressed between the eyes; antennomeres I-IV narrower, IV-VII slightly compressed; fore femora simple, not toothed; fore tibiae not arched.

Distribution: French Guiana (Figs. 66, 68).

\section{Macromalthinus santaremensis Brancucci, 1981} (Fig. 53)

Macromalthinus santaremensis Brancucci, 1981a: 264.

Material examined: HOLOTYPE ơ: [BRAZIL, Pará] Santarém (NHMB) (Fig. 53).

Differential diagnosis: Head black; pronotum pale yellow, elytra black with apical yellow patches; males: fore femur swollen, with a distinct acute ventral tooth on distal third; aedeagus with right prolongation of tegmen broadly projected dorsally; left setiferous prolongation short; right paramere present.

Macromalthinus santaremensis differs from M. maximiceps and $M$. belemensis by the presence of right paramere. It differs from the other Amazonian species by truncate ventral tooth on fore femur of males.

Distribution: Brazil (Pará state) (Fig. 66).

Remarks: Species described on a single male labelled 'Brésil, Santarem', preserved in NHMB. No other specimens are known so far. The holotype lacks some tarsi and last antennomeres. The specimens collected in French Guiana, initially named as M. santaremensis by
Constantin (2016), are similar to the male holotype in the body shape and genitalia, but additional material reveals new elusive characters leading to the description of M. guyanensis n. sp. and M. orapuensis n. sp.

\section{Macromalthinus schmidli Constantin, 2010} (Fig. 54)

Macromalthinus schmidli Constantin, 2010a: 24.

Material examined: HOLOTYPE ơ: ECUADOR. Zamora, Estación Científica San Francisco, Loma Moras, 0358'30"S, $79^{\circ} 04^{\prime} 38^{\prime \prime}$ W, 2,000 m, X.2008, J. Schmidl (NHMB) (Fig. 54).

Differential diagnosis: Head, pronotum and elytra entirely black; males: fore femur strongly swollen with a small, sharp, apical ventral tooth; aedeagus with right prolongation of tegmen broad; left setiferous prolongation short; females: ventrite VII wide, lateral margins broadly arched, posterior margin slightly projected.

Macromalthinus schmidli differs from all the other species by head, pronotum and elytra entirely black, and fore femur of males strongly swollen, with a small apical ventral tooth.

Distribution: Ecuador (Fig. 66).

\section{Remarks on morphology}

One of the diagnostic characters ascribed for Macromalthinus is the abdomen of males curved under itself in rest position (Brancucci, 1981a) (Fig. 59). Actually, this curvature is the consequence of dehydration of the broad membranes between abdominal ventrites (Fig. 60) and depends on the killing and preserving methods applied to the specimens. When alive, the abdomens of males are normally straight (Fig. 61).

Female genitalia of Macromalthinus species (Fig. 62) have characters in common with both members of Chauliognathini and Ichthyurini genera, according to the general morphological configuration outlined by Brancucci (1980). In all studied species, the vagina is sacciform, abruptly constricted before bursa copulatrix; oviduct joining vagina ventrally; accessory gland dorsally; bursa copulatrix globose, very small; spermatheca consisting of a tuft of spiralling filaments joining the bursa copulatrix anteriorly by a short duct.

According to Brancucci (1980), the wings of Chauliognathinae are somewhat constant, with minor differences distinguishing the two tribes, Chauliognathini and Ichthyurini. Macromalthinus species show the same general aspect of that described by Brancucci (1980) as 'type Chauliognathus': wing veins reduced; veins $r$ and $r$-m present; radial cell $2 R_{1}$ closed; vein $R r$ extending just until meeting point with $r-\mathrm{m}$; vein $\mathrm{Mr}$ sclerotized; transversal vein cu-a absent; margin of anal area slightly sinuous. However, some of the differences observed in Macromalthinus species from that basic model resemble 
the Ichthyurini wings highlighted by Brancucci (1980): wings much longer and narrower; base much narrower than distal half; vein Cu straight, without distinct limits from $\mathrm{M}_{3+4}$; vein $\mathrm{Ax2}$ fading, not visible throughout its length; vein $M r$ running very close to $M_{3+4}$ (Fig. 58).

Morphologically, two main groups of species can be recognized in Macromalthinus. In the first, composed of M. maximiceps, M. belemensis, $M$. santaremensis, M. globuliventris, M. schmidli, M. guyanensis sp. nov., M. orapuensis sp. nov., M. piceiventris sp. nov. and M. luteoapicalis sp. nov., the specimens are larger, more robust and with a strong constriction near the anterior angles of pronotum (Figs. 7-10), and aedeagus with a large and broad right prolongation of tegmen (Figs. 31-34). The second group is composed of $M$. brasiliensis, $M$. xerophilus sp. nov. and M. quadratithorax sp. nov. Specimens of these species are smaller, with a subquadrate pronotum (Figs. 11-12), without strong constrictions near anterior angle; right prolongation of tegmen shorter and narrower (Figs. 35-36).

The setiferous prolongation can be very long (M. maximiceps, $M$. belemensis, $M$. santaremensis, M. luteoapicalis sp. nov.) (e.g., Fig. 32) to short and broad (M. globuliventris, M. schmidli, M. piceiventris sp. nov., M. guyanensis sp. nov., M. orapuensis sp. nov., M. quadratithorax sp. nov.) (e.g., Figs. 31, 33-35), or totally absent ( $M$. xerophilus sp. nov., M. brasiliensis) (Figs. 36, 65). According to Brancucci (1981a), the genus encompasses typical, morphologically resembling species, except for $M$. brasiliensis, which
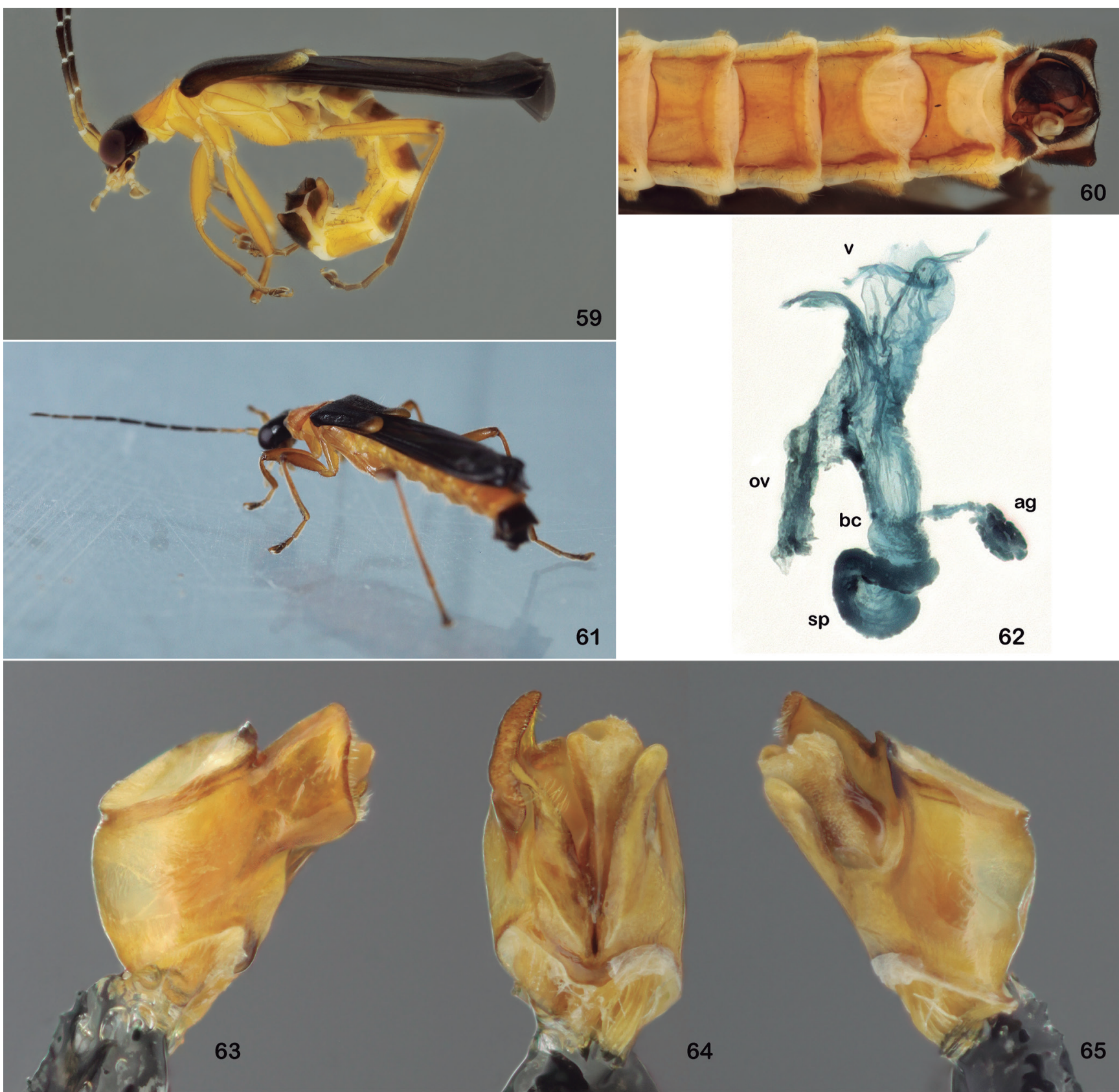

Figures 59-65: Morphology of Macromalthinus brasiliensis. (59) Habitus of male, lateral view. (60) Abdomen of male, ventral view. (61) Live specimen, male. (62) Genital organs of female, lateral view. (63-65) Aedeagus, left, dorsal and right view. Abbreviations: ag = accessory gland, bc = bursa copulatrix, ov = oviduct, $\mathrm{sp}=$ spermatheca, $\mathrm{v}=$ vagina. 
seemed to be the transition between Macromalthinus and Maronius. Macromalthinus xerophilus sp. nov. and M. quadratithorax sp. nov. resemble $M$. brasiliensis in the pronotum with feebly constricted lateral margins, and tegmen with narrower right prolongation and absence of setiferous prolongation.

\section{Distribution and natural history of Macromalthinus}

Distributional data known prior to this work showed restricted distribution records and wide disjunction of species (Brancucci, 1981a; Constantin, 2010a, 2016). The species of this genus were recorded only from French
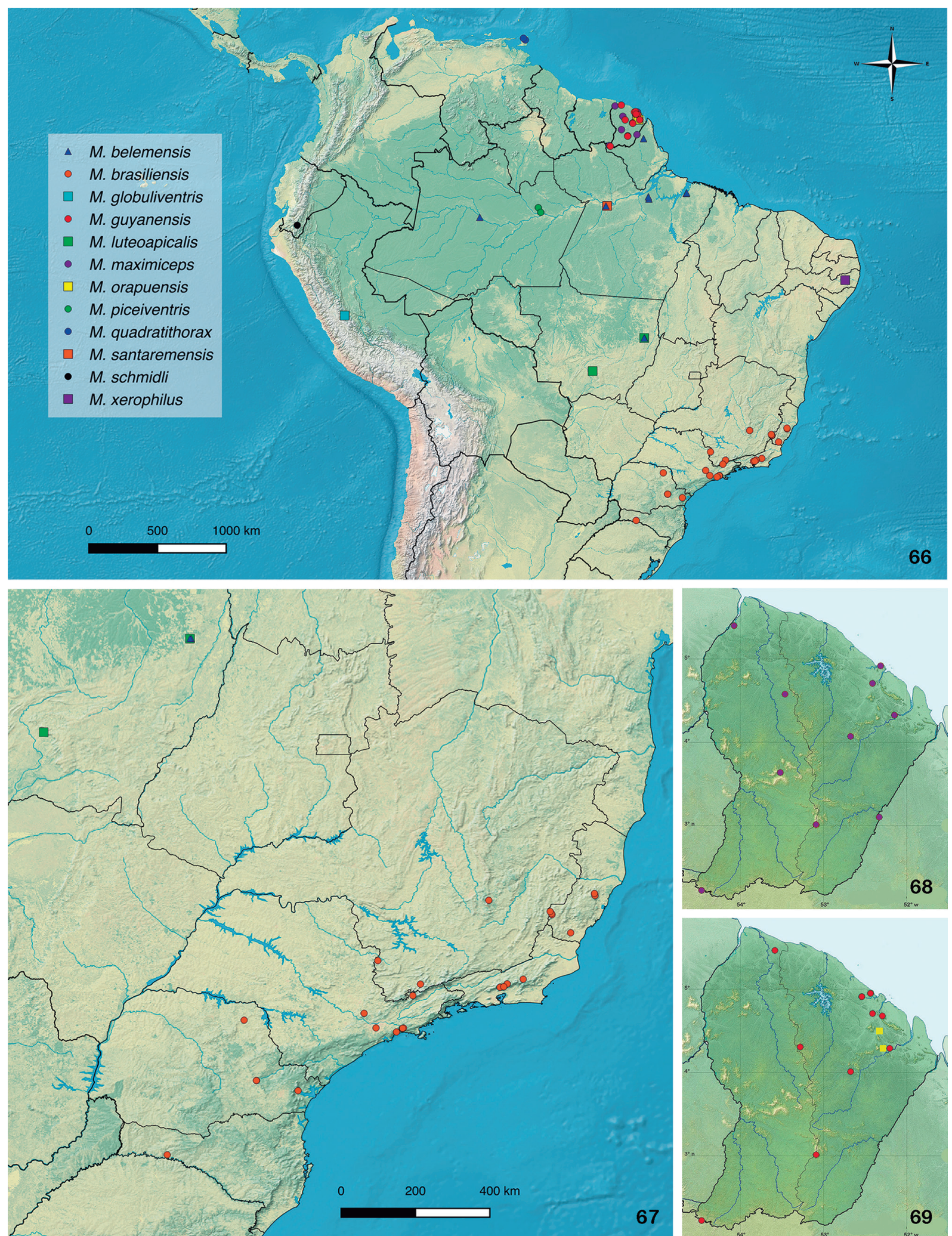

Figures 66-69: Distribution of Macromalthinus species. (66) Distribution of Macromalthinus species in South America. (67) Distribution of M. brasiliensis in Brazil. (68) Distribution of M. maximiceps in French Guiana. (69) Distribution of M. guyanensis sp. nov., and M. orapuensis sp. nov. in French Guiana. Background maps of Figs. 66-67 by Natural Earth (available at: www.naturalearthdata.com), and Figs. 68-69 by Eric Gaba. 
Guiana (M. maximiceps), Ecuador (M. schmidli), Peru (M. globuliventris), northern (M. belemensis, $M$. santaremensis) and southeastern Brazil (M. brasiliensis). New records fill wide distributional gaps of Macromalthinus species in South America and approximate formerly widely separated species (Figs. 66-69).

Some species are still known only from single or nearby localities, like M. globuliventris, M. schmidli and M. santaremensis, whereas for others the known distribution is broadly expanded, like for $M$. maximiceps, $M$. belemensis and $M$. brasiliensis. Members of the genus are recorded for the first time in Trinidad and Tobago (Trinidad Island) and in northeastern, middle-western and southern Brazil, embracing a wide range of biomes, vegetation types, climates and altitudinal ranges. Most of the species inhabit very humid, sometimes flooded regions and gallery forests in central Amazon (like M. belemensis, M. santaremensis and M. piceiventris sp. nov.) or along the northern and southern reaches of Amazon (like M. maximiceps, M. orapuensis sp. nov., M. guyanensis sp. nov. and M. Iuteoapicalis sp. nov.). Macromalthinus brasiliensis is widespread in several vegetation types along the southern and southeastern Brazilian Atlantic forest, like the coastal tropical moist broadleaf restinga forest at the seashore, campos rupestres highlands (shrubby montane savannas), montane forests, dryer inland areas and in small forest patches in metropolitan areas (São Paulo city). In contrast, $M$. xerophilus sp. nov. is only recorded from a transition zone between the Atlantic forest and the semiarid caatinga. The specimens are usually collected with malaise traps or by sweeping the lower shrubby vegetation.

Nothing is known about feeding habits of Macromalthinus. It seems that there are not specific food sources, as seen by the wide distribution of some species throughout such distinct vegetation types, biomes and altitudinal ranges.

\section{ACKNOWLEDGEMENTS}

We are grateful to the curators listed in Material and methods for providing loans and granting access to collections and specimens under their charge, specially to Orlando Silveira (MPEG), Isabelle Zürcher (NHMB) and Michael Geiser (BMNH) for sending pictures and additional information on type specimens. Also to Simone P. Rosa (UNIFEI) for the donation of specimens to the MZUSP and Danilo C. Ament (FFCLRP) for his help in tracking Macromalthinus specimens in Brazilian collections. The senior author thanks especially the S.E.A.G., mainly Stéphane Brûlé, Pierre-Henri Dalens, Serge Fernandez, Eddy Poirier, Frédéric Robin and Julien Touroult for their wide surveys in French Guiana, and the authorities and managers for the facilities granted to SEAG surveys in protected areas and other natural areas: Nouragues Nature Reserve (CNRS, ONF), Réserve of Mont Grand Matoury, Réserve Trinité, Réserve Biologique of Mont Lucifer, Amazonian Park of French Guiana (Belvedere of Saul, Mont Saint-Marcel, Mont Itoupé and Mitaraka mas- sif). For the remarkable material of the remote massif of Mitaraka, we thank the expedition "The Revisited Planet" French Guiana 2014/2015 which was co-organized by the MNHN and Pro- Natura International, and supported by European funding FEDER, the Regional Council of French Guiana (FG), the General Council of FG, the French Ministry of Higher Education and Research (DRRT), the Directorate of Environment, Planning and Housing (DEAL) of FG. Thanks to Juares Fuhrmann (MZUSP) for the line drawings and to Sônia Casari (MZUSP) for the suggestions and careful reading of the manuscript. This work was supported by grants to GB from Conselho Nacional de Desenvolvimento Científico e Tecnológico (CNPq-142074/2013-6) and Fundação de Amparo à Pesquisa do Estado de São Paulo (FAPESP-2013/08966-1; FAPESP-2015/21273-0).

\section{REFERENCES}

Alcoforado-Filho, F.G.; Sampaio, E.V.S.B. \& Rodal, M.J.N. 2003. Florística e fitossociologia de um remanescente de vegetação caducifólia espinhosa arbórea em Caruaru, Pernambuco. Acta Botanica Brasilica, 17(2): 287-303. DOI

Biffi, G. \& Casari, S.A. 2017. Comparative morphology of immatures of neotropical Chauliognathinae (Coleoptera, Cantharidae). Zoologischer Anzeiger, 267: 111-138. DOI

Blackwelder, R.E. 1945. Checklist of the coleopterous insects of Mexico, Central America, the West Indies and South America. Bulletin United States National Museum, 185(3): 345-550.

Brancucci, M. 1980. Morphologie comparée, évolution et systématique des Cantharidae (Insecta: Coleoptera). Entomologica Basiliensia, 5: 215-388.

Brancucci, M. 1981a. Révision du genre Macromalthinus Pic (Col. Cantharidae). Entomologische Arbeiten aus dem Museum G. Frey, 29: 259-272.

Brancucci, M. 1981b. Révision du genre Maronius Gorham et notes sur les genres voisins (Coleoptera: Cantharidae). Entomologica Basiliensia, 6: 328-367.

Brown, E.H. 1970. Introduction. Geographical Research on the Royal Society/ Royal Geographical Society's Expedition to North-Eastern Mato Grosso, Brazil: A Symposium. [Brown, E.H.; Askew, G.P.; Thornes, J.B.; Young, A.; Townshend, J.R.G. \& Daultrey, S.G. Eds.]. The Geographical Journal, 136(3): 365-367.

Constantin, R. 2010a. A contribution to knowledge of the Cantharidae (Coleoptera, Elateroidea) in Ecuador and French Guiana. Entomologica Basiliensia et Collectionis Frey, 32: 7-29.

Constantin, R. 2010b. Les genres de Cantharidae, Lampyridae, Lycidae et Telegeusidae de Guyane Française (Coleoptera, Elateroidea). Le Coléoptériste, Paris, (Suppl. 2): 32-45.

Constantin, R. 2016. Contribution à l'étude des Chauliognathinae de la Guyane et description de cinq espèces nouvelles (Coleoptera, Cantharidae). Le Coléoptériste, Paris, 10(Suppl.): 3-33.

Constantin, R. \& Chaboo, C.S. 2016. Beetles (Coleoptera) of Peru: A Survey of the Families. Cantharidae Imhoff, 1856. Journal of the Kansas Entomological Society, 89(2): 195-201. D0I

Delkeskamp, K. 1939. Coleopterorum Catalogus, Pars 165, Col. Cantharidae. The Hague, W. Junk. 357p.

Delkeskamp, K. 1977. Coleopterorum Catalogus Suplementa, Pars 165, fasc 1. Col. Cantharidae. The Hague, Dr. W. Junk. 485p.

Liberti, G. 2005. Improved solutions of two water-soluble media for mounting beetle genitalia. The Coleopterist, 14(1): 29-35. 
Magis, N. \& Wittmer, W. 1974. Nouvelle répartition des genres de la sousfamille des Chauliognathinae (Coleoptera, Cantharoidea: Cantharidae). Bulletin de la Société Royale des Sciences de Liège, 43(1-2): 78-95.

Mendes, C.B.; Khattar, G.; Biffi, G.; Macedo, M.V. \& Monteiro, R.F. 2015. Altitudinal distribution and sex ratio of two Cantharidae (Coleoptera) species in Parque Nacional da Serra dos Órgãos. In: International Symposium of Entomology, 50. Proceedings. Viçosa, MG, Universidade Federal de Viçosa. p. 139.

Miskimen, G.W. 1961. A new family of beetles found in the Cantharoidea. The Coleopterists Bulletin, 15(1): 17-25.

Pic, M. 1906. Nouveaux coléoptères d'Europe, Asie, Afrique et Amérique. L'Echange, Revue Linnéenne, 22(254): 9-12.
Pic, M. 1919. Nouveautés diverses. Mélanges exotico-entomologiques, 31: 11-24. DOI

Ribeiro, J.E.L.S.; Hopkins, M.J.G.; Vicentini, A.; Sothers, C.A.; Costa, M.A.S.; Brito, J.M.; Souza, M.A.D.; Martins, L.H.; Lohmann, L.G.; Assunção, P.A.; Pereira, E.C.; Silva, C.F.; Mesquita, M.R. \& Procópio, L.C. 1999. Flora da Reserva Ducke. Guia de identificação das plantas vasculares de uma floresta de terra firme na Amazônia Central. Manaus, INPA-DFID. 816p.

Tostain, 0. 2017. Biotope, Znieff 030030063, Stations à Bactris nancibaensis de la crique Orfion. Paris, INPN, SPN-MNHN. 7p. Available at: https://inpn. mnhn.fr/zone/znieff/030030063.pdf. Access in: 14/03/2018.

Wittmer, W. 1963. Neue neotropische Malacodermata aus dem Museum G. Frey. Entomologische Arbeiten aus dem Museum Georg Frey, 14: 128-135. 